\title{
Yükümlülük kipliği ve klasik Türkçe tıp metinleri ilişkisi
}

Meryem ARSLAN2

\begin{abstract}
APA: Arslan, M. (2019). Yükümlülük kipliği ve klasik Türkçe tıp metinleri ilişkisi. RumeliDE Dil ve Edebiyat Araşturmaları Dergisi, (17), 612-638. DOI: 10.29000/rumelide.659351
\end{abstract}

\section{$\ddot{O} \mathbf{z}$}

Tıp metinlerinin yükümlülük kipliği için uygun metin türlerinden biri olduğu varsayımına dayananan bu çalışmanın konusu klasik Türkçe tıp metinleri ile yükümlülük kipliği ilişkisidir. Çalışma, klasik Türkçe tıp metinleri, yükümlülük kipliğinin kullanımına uygun mudur, klasik Türkçe tıp metinleri hangi özellikleri yönüyle yükümlülük kipliği ile ilişkilendirilebilir, klasik Türkçe tıp metinleri yükümlülük kipliği kiplik alanlarından hangisine dâhil edilmelidir temel sorularından oluşmaktadır. Bu temel sorular, 14. ve 19. yüzyıllar arasında yazılmış 10 klasik Türkçe tıp metninden örneklerle cevaplandırılmaya çalışılmıştır. Çalışmada, yükümlülük kipliğinin alanyazınında kabul görmüş yönleri ile tıp metinlerinin özellikleri karşlaştırılmıştır. Karşılaştırmanın yapılacağı ölçek konumundaki yükümlülük kipliğinin temel unsurları (sınırları, tanımı, kipliğin kaynağı ve kiplik alanı gibi), Palmer, van der Auwera-Plungian, Erk Emeksiz, Corcu Gül, Papafragou, Kratzer, BybeePerkins-Pagliuca ve Nuyts-Byloo-Diepeveen’in görüşleri ile belirlenmiştir. Çalışmada klasik Türkçe tıp metinlerinin, yükümlülük kipliği ile ilgili tüm tartışmaları içerecek örneklere ve kullanımlara sahip bir metin türü olduğu ortaya çıkmıştır. Buna göre klasik Türkçe tıp metinlerinde konuşur yani hekim, tedavi olmak isteyen kişilere göre bilgisine güvenilen ve sağlık konusunda söz sahibi olan otorite konumundadır. Yükümlülük kipliği, ilgili kiplik türünün kiplik anlamlarının tamamını örneklendirebilir bir metin türüne sahiptir. Yine bu çalışmayla Papafragou'da ortaya konulan ve kısaca gereklilik ve zorunluluk kiplik alanları olarak belirtilen kiplik alanları içerisinde tıp metinlerinde rastlanan ve kanunlar ile kurallar gibi herkesi değil yalnızca ilgili durumdaki kişileri kapsayan yaptırımların hangi alana dâhil edileceği mevzusunun tartışmaya açık olduğu ortaya çıkmıştır. Böyle bir durum için Papafragou'nun alanlarına tıp ve sağlık başlığının ayrıca alınması gerektiği önerilmiştir.

Anahtar kelimeler: Kiplik, yükümlülük kipliği, metin, klasik Türkçe tıp metinleri.

\section{The relationship between deontic modality and classical Turkish medical texts}

\begin{abstract}
The topic of this study, which is based on the assumption that medical texts are one of the suitable text types for deontic modality, is the relation between classical Turkish medical texts and deontic modality. The study consists of the basic questions; are classical Turkish medical texts suitable for the usage of deontic modality, in what features can classical Turkish medical texts be related to deontic modality, and in what modality areas of deontic modality should classical Turkish medical
\end{abstract}

1 Bu çalışma TÜBİTAK tarafından 2017 Yllı 1059B191601402 numaralı 2219 Yurt Dıșı Doktora Sonrası Araştırma bursuyla desteklenen Klasik Türkçe Tıp Metinlerinde Gereklilik ve Yükümlülük Kipliği adlı projenin varsayımını geliştirmek ve zenginleștirmek için ve onun alanyazınından ve bazı tespitlerinden yararlanılarak hazırlanmıștır. Konu doğrudan projenin konusu değildir. Ancak proje sırasında oluşturulduğu için bu projeyi destekleyen TÜBİTAK Bilim İnsanı Destek Programları Başkanlığı’na teşekkür etmeyi bir borç bilirim.

2 Dr. Öğr. Üyesi, Niğde Ömer Halisdemir Üniversitesi, Fen Edebiyat Fakültesi, Cağdas Türk Lehceleri ve Edebiyatları Bölümü (Niğde, Türkiye), meryemarslan2078@hotmail.com, ORCID ID: 00oo-0002-1621-0286 [Makale kayit tarihi: 28.10.2019-kabul tarihi: 20.12.2019; DOI: 10.29000/rumelide.659351] 
texts be included. These basic questions were attempted to be answered with examples from 10 classical Turkish medical texts written between 14. and 19. centuries. In the study, deontic modality's well-accepted aspects in the body of literature and the features of medical texts were compared. The primary elements (such as its boundaries, definition, source of modality, and area of modality) of the deontic modality at the scale on which the comparison will be made was determined with the opinions of Palmer, van der Auwera-Plungian, Erk Emeksiz, Corcu Gül, Kratzer, Bybee-Perkins-Pagliuca and Nuyts-Byloo-Diepeveen. It was revealed in the study that the classical Turkish medical text was a text type that possessed examples and usages that would include all arguments regarding deontic modality. According to this, the speaker, which is the doctor, is at the position of authority whose knowledge with respect to the person looking to be cured is trusted, and who has a say in the topic of health. The meanings discussed within the modality senses of the deontic modality are located in the aforementioned texts. Again in this study, it was revealed that the issue of the sanctions that are included in Papafragou and which are briefly referred to as the modality of obligation and necessity which is found in the medical texts and which covers not only everyone but the people concerned, such as laws and rules, is open to discussion. It has been suggested that Papafragou's fields of medicine and health should be taken separately.

Keywords: Modality, deontic modality, text, classical Turkısh medical texts.

\section{Giriş}

Başlangıcı milattan önceki yüzyıllara kadar götürülebilen kiplik, ortaya çıtı̆̆ı süreye göre hâlâ güncelliğini koruyabilen ve dolayısıyla yıllara meydan okuyabilen niteliğe sahiptir. Tartışılmaya başlandığı mantık alanındaki birikimler, ona mantık çalışmalarında ayrı bir yer verilmesini sağlamıştır. O, Aristo ile başladığı kabul edilen yolda, Ortaçağ İslam düşünürlerince geliştirilmiş ve Lewis ${ }^{3}$, Leibniz, Carnap, Kripke, Kant’ın görüşleri sonrasında yani sıkı gerektirme, mümkün dünyalar semantiği, Kripke semantiği gibi düşüncelerle önemli bir aşama kayderek modal mantık/kiplik mantığı olarak adlandırılmaya başlanmıştır. İşte bu noktada bu yeni görüşler onun yalnızca adının ve kapsamının değişmesini sağlamamış, aynı zamanda diğer bilim dallarında da insanlığı etkileyecek önemli çalışmaların yapılmasına ufuklar açmıştır (Malak, 2013: 64-99; Çetres, 2014; Ural, 1995; Öner, 2009 )4. Bu alanlardan biri de dil bilimdir. Özellikle kipliğin anlamla bağ kurulması yönü dil bilimsel kiplik çalışmalarını önemli ölçüde etkilemiştir. Kipliğin dil bilimsel incelenmesi alanında çalışmaları bulunanların da eserlerinde bu yönü vurguladıkları görülebilir (Aslan Demir, 2008; Çetin, 2011).

3 Lewis'ın 1918 yılında yayımladığı Survey of Symbolic Logic kitabıyla kipsel önermelerin modern mantıkta kipsel önermelerin ele alınmaya başladığ ifade edilmektedir. Lewis bu eserinde doğruluk değerleriyle uyum içinde zorunluluk ve imkân kipliklerini kullanarak kipsel mantığın yeniden ele alınıp kullanılmasını sağlamıştır (Köz, 2003: 164)

Kiplik mantığının uygulamalı bilimler gibi dil bilimini de etkilemesi yeniçağda başlayan ve günümüzde de devam eden kiplik tartışmalarına kadar uzanabilir. Kiplik mantığının Kripke semantiği olarak adlandırılan görüşü, uygulamalı bilimleri etkilemiștir. Temelde mümkün dünyalar fikrinden doğan bu görüs, Carnap tarafindan geliștirilmiş ve son halini Kripke'yle almıştır. Yaşadığımız dünyanın mümkün dünyaların en iyisi olduğu görüşünde olan Leibniz'e göre önermeler, bütün mümkün dünyalarda doğru ise zorunlu; en az bir mümkün dünyada doğru ise mümkündür. Mümkün dünyalara daha cok sezgisel yaklasımı ileri süren Carnap ise kiplik önermelerinin, kiplik anlamları açılandıktan sonra yeterli bir sistem kurularak belirlenmesi gerektiğini savunmuştur. Ona göre bir modalite, modaliteye karşıllk gelen semantik kavram arasında ilişki kurulması'yla gerçekleşebilir. Örneklemek gerekirse, isteme kipliği, isteme anlamı; yükümlülük kipliği yükümlülük anlamı belirlenerek tespit edilebilir. Anlam ve kiplik arasında kurulan bağ, modalitelerin izah edilmesi ve bağlantıda karşılaştıkları sorunların açıklanmasını kolaylaştırmıştır. Bu mantıksal ilişkiyi yani kiplik ve anlam bağını kuramadıkları için önceki dönemdeki aynı önermelerin, bazen doğru ve bazen de yanlış olarak değerlendirildiği ifade edilmektedir. Kripke ise mümkün dünyalar semantiğini/bağıntılı semantik/çerçeve semantiğini şimdiki formuna ulaştırmış ve bunu ilk olarak kiplik mantığında kullanmıştır. O, 1963'te mümkün dünyaları değerleme ile nitelendirerek modelin eksiksizlik ve karar verilebilirlik sonuçlarını elde etmis ve böylece bağıntılı yapılar ile normal sistemler oluşturmaya çalışmıştır. Kripke semantiğinde, önermelerin doğruluk değerini (değerlemesini) veren bağıntılı yapılar, matematik, bilgisayar bilimi, yapay zekâ ve dil biliminde kullanılmaya başlanmıştır (Malak, 2013: 64-99).

Adres
Adress

Kirklareli University, Faculty of Arts and Sciences, Department of Turkish Language and Literature, Kayalı Campus-Kırklareli/TURKEY e-mail: editor@rumelide.com 
Van der Auwera ve Aguilar5, modality sözcüğünün Batı'daki tarihçesi ile ilgili açıklamalarında, doğrudan olmasa da, kiplik mantığının dil bilimsel kiplik incelemelerine olan etkisini de anlatmıştır:

\begin{abstract}
"Kant'la birlikte modality teriminin kullanımı artmış ve öncelikle felsefede, mantıkta ve yalnızca Alman geleneğinde değil dil biliminde de Boethius tarzı mood anlamının yerini almıştır. ... Ingilizce gramerde açı veya güçlü Kantçı etkilerin olmaması ilginçtir: Daha önce de belirtildiği gibi, Jespersen ... modality terimine gerek duymamıştır... yirminci yüzyılın başlarında, İngiliz dil biliminde, modality teriminin tamamen bulunmadığı söylenemez. İlgi çekici bir kullanım Sapir'de ... Zandvoort'un dil bilgisinde... Lyons'un [çalışması] da bulunur. Bu dönem, İngiliz dil biliminde modality'nin önem kazandığı bir dönem olmuştur. Ancak Lyons bu değişikliği gerçekleştiren tek dil bilimci değildir. Büyük oyuncular, Leech (ve takipçileri), Halliday (ve takipçileri), Palmer (ve takipçileri) ve Coates'tu... Değişimin önemli bir katalizörü Palmer'di. Onunla, ilginç bir şekilde, mantık ve felsefeye dönen dil bilimine bir kez daha şahit olduk. Bu kez ilham kaynağı Kant değil, Palmer’in "modal mantık konusunda öncü bir çalışma" olarak gördüğü von Wright idi. Palmer, von Wright'ın çalışmasına ... modality türleri arasında yaptığı ayrımlardan dolayı büyük ilgi gösteriyordu. Von Wright'a göre modality'nin dört türü vardı: Aletik, epistemik, deontik ve varoluşçu. Burada ayrıntılar önemli değil, ancak dört kavramın ikisi ("epistemik modalite" ve "deontik modalite"), genel olarak, ilgili dil bilim kategorileri olarak kabul edilmektedir. İlginçtir, von Wright modality terimini kulland,, fakat onu Latince modus'un Boethius tarzı anlamı olan mode ile değiştirdi. Bununla birlikte, Palmer'de, sadece von Wright'ın modality'si kullanıldı, çünkü o, başka bir şey için yani Protagoras ve Dionysius'un mood anlamı için, mood'a ihtiyaç duymuştur" (van der Auwera-Aguilar, 2016: 25-27).
\end{abstract}

Açıklamalarda da görüldüğü gibi dil bilimsel kiplik çalışmalarındaki kiplik mantığı etkisi ile ilgili olarak van der Auwera ve Aguilar'da (van der Auwera-Aguilar, 2016) geçen, "Palmer'le birlikte biz dildeki kiplik çalışmalarını felsefe ve mantı̆̆a dönmesine bir kez daha şahit olduk" ile "modal mantık konusunda öncü bir çalışma”nın düşünürü olan “von Wright’ın görüşlerinden yararlandı” ifadeleri, bu yönden çok manidardır.

Kiplik mantığındaki tartışmaların dil bilimsel kiplik çalışmalarına zemin hazırlaması ve dil bilimsel kiplik çalışmaları için zaman zaman kiplik mantığı çalışmalarına dönülmesi bir anlamda dile kiplik mantı̆̆ındaki birikimin penceresinden bakılması anlamına gelmektedir. Bu durumu da bu alanda çalışma yapan çoğu dil bilimci, çalışmalarının bir yerinde mutlaka dile getirmişlerdir. Ancak kiplik mantı̆̆ının, dil bilimsel kiplik çalışmalarına etkisi üzerindeki uzlaşı, dil bilimsel kiplik çalışmalarındaki kiplik mantığı etkisinin boyutları söz konusu olduğunda ise yerini görüş ayrılıklarına bırakır6 (Kerimoğlu, 2011: 9; Uzdu Yıldız, 2011: 41-42; Jahangirov, 2011: 298-299). Kiplik mantığının dil bilimsel kiplik çalışmalarına etkisinin boyutları, iki disiplin arasında yapılacak karşılaştırmalı çalışmalarla net bir şekilde ortaya konulabilecektir, ama çalışmanın konusu bu değildir. Burada konu gereği dil bilimsel kiplik incelemelerine kısaca değinilecek ve özellikle kiplik-metin ilişkisi ortaya konulmaya çalışılacaktır.

Dil bilimsel kiplik çalışmalarında, genel olarak kipliğin, sınırlarına, çeşitlerine, ilgili olduğu diğer dil bilim dallarına (Kerimoğlu, 2011; Palmer, 2001; van der Auwera-Plungian, 1998; Lyons 1977; Aslan Demir, 2008; Torun, 2013) değinilirken son zamanlarda kiplik çalışmalarının, kiplik-metin/söylem

Alıntıda: modality, mood, mode ile must, may, can gibi yardımcı fiiller çevrilmeden bırakılmıştır. Çünkü bu sözcüklerin Türkçedeki karşllıklarının onları tam olarak anlatamayacağı düşünülmüsștür. Ayrıca alıntının alındığı makale Türkçeye çevrilmiştir. Makalenin yayın haklarının bulunduğu Oxford University Press'in yayınla ilgili istekleri tamamlanır tamamlanmaz çevirinin yayımlanması düşünülmektedir.

Kerimoğlu’na göre dil bilimsel kiplik çalışmaları, özellikle temel ögeler bağlamında kiplik mantığına dayanır (Kerimoğlu, 2011: 9). Uzdu Yıldız, iki alanın aynı anlamı yansıtması yönüyle birbirine benzediğini ama aynı anlamın ifade edilmesi noktasında farklı yaklașımlar geliștirdiğini belirtir. Buna göre mantıksal cözümleme, anlamaya, dil bilimsel çözümleme betimlemeye yöneliktir. Dil bilimsel çözümlemede kipliğin dilsel ögelerle nasıl yansıtıldığı bulunmaya çalışılırken mantıksal çözümlemede bu özellikler, gereklilik, zorunluluk ve diğer kavramlarla sistemleştirilmektetir (Uzdu Yıldız, 2011: 41-42). Jahangirov'a göre kiplik mantığı ile dil bilimsel kiplik çalıșmaları arasındaki fark, açıklanamaz derecededir. Kiplik mantığı ile dil bilimsel kiplik arasında belirgin farklılığın olmaması, onlar arasında karşılaştırma yapılırken güçlükler çıkarmakta ve tartışmalara neden olmaktadır (Jahangirov, 2011: 298-299). 
ilgisisiyle ele alınması gerektiği de öne çıkmaya başlamıştır. Bu gelişmede kiplik anlamların belirlenmesinde yalnızca biçimlerin yeterli olmaması, onların anlamlandırılmasında bağlamın öneminin farkedilmesi etkili olmuştur. Nitekim bunun sonucunda kiplik-metin ilgisine dikkat çeken çalışmalar yapıldığı gözlenmiştir7. Bu tür çalışmalara katkı sağlamak ve kiplik-metin ilişkisine kiplikmetin türü açısından malzeme sunmak için çalışma konusu, yükümlülük kipliği ve klasik Türkçe tıp metinleri olarak seçilmiştir.

\section{1. Çalışmaya dair}

Çalışmanın konusu klasik Türkçe tıp metinleri ile yükümlülük kipliği ilişkisidir. Çalışma, klasik Türkçe tıp metinleri, yükümlülük kipliğinin kullanımına uygun mudur, klasik Türkçe tıp metinleri hangi özellikleri yönüyle yükümlülük kipliği ile ilişkilendirilebilir, klasik Türkçe tıp metinleri yükümlülük kipliği kiplik alanlarından hangisine dâhil edilmelidir temel sorularından oluşmaktadır. Bu temel sorular, 14. ve 19. yüzyıllar arasında yazılmış 10 klasik Türkçe tıp metninden örneklerle cevaplandırılmaya çalışılmıştır.

Çalışmada, yükümlülük kipliğinin alan yazınında kabul görmüş yönleri ile tıp metinlerinin özellikleri karşılaştırılmıştır. Karşılaştırmanın yapılacağı ölçek konumundaki yükümlülük kipliğinin temel unsurları (sınırları, tanımı, kipliğin kaynağı ve kiplik alanı gibi), Palmer; van der Auwera-Plungian; Erk Emeksiz; Corcu Gül; Kratzer; Bybee-Perkins-Pagliuca ve Nuyts-Byloo-Diepeveen’in görüşleri ile belirlenmiştir (Palmer, 2001; van der Auwera-Plungian, 1998; Erk Emeksiz, 2008; Corcu Gül, 2005; Kratzer, 1981; Bybee-Perkins-Pagliuca, 1994, Nuyts-Byloo-Diepeveen, 2005). Ayrıca klasik Türkçe tıp metinlerinin, yükümlülük kipliği kiplik alanı için dışarıdan kaynaklı zorunluluk olarak gösterilen normlar, genel kurallar gibi alanların içerisinde yer alıp alamayacağı tartışılmıştır.

\section{2. Çalışmanın verilerini oluşturan tıp metinlerinin kısaca tanıtımı}

Edviye-i Müfrede (EM): Türkçe olarak kaleme alınan ve tarihi bilinen ilk eser olarak kabul edilen Edviye-i Müfrede'nin müellifi, XIV. Yüzyılda yetişmiş ünlü bir tıp bilgini olan Hacı Paşa adıyla bilinen Celâlüddin Hızır'dır. Eser, Canpolat ve Önler tarafından kitap olarak hazırlanmıştır (Canpolat-Önler, 2007). Çalışmada kullanılan örnekler için bu eser esas alınmıştır.

Gayetü'l-Münteha Fi-Tedbiri'l-Merza (GM): Müderris Hasan Efendi'nin Gayetü'l-Münteha FiTedbiril'-Merza adlı tıp eseri, 18. yüzyılda yazılmıştır. Türkçe çalışmaları için önemli söz varlığı ve dil özellikleri bulunan eserle ilgili olarak Dinar doktora tezi hazırlamıştır. Çalışmada bu tezden yararlanılmıştır (Dinar, 2013).

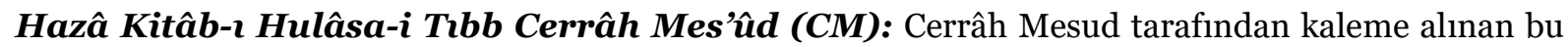
tıp kitabı, 15. yüzyıl tıp metinleri arasında yer alır. Bu eserde anlatılan açık beyin ameliyatı ve bu ameliyatın açık bir şekilde yapılması tıp tarihi açısından oldukça önemlidir. Eser üzerinde Uçar tarafından bir doktora tezi hazırlanmıştır (Uçar, 2009). Çalışmada eserden kullanılan veriler için bu kaynaktan faydalanılmıştır.

Kitâab-ı Âkrâbâdîn (KA): 14. yüzyllda yazılmış eser, Hekim Hayreddin bin Bâyezit bin Şâhi'nin Hulâsatu't-Tıbb adlı eserinin devamında yer alan ilaç yapımı ile ilgili bilgilerin bulunduğu bölümdür. Eser, dönemindeki Türkçenin özelliklerini yansıtabilecek ve tıp metinlerinde söyleyiş kolayllğı

Bunların birkaçı için şu örnekler verilebilir: (Demirtaş, 2008; Güven, 2015; Rentzsch, 2011) 
oluşturabilecek şekilde yazılmıştır. Eser üzerine Yavuz’un bir yüksek lisans çalışması bulunmaktadır. Eserdeki metin örnekleri bu tezden alınmıştır (Yavuz, 2008).

Müntehâb-ı Şifâ (MŞ): Celâlüddin Hızır'ın Türkçe yazdığı en önemli eseridir. Yazılış yılı ve müellifi konusunda herhangi bir kaydı bulunmamaktadır. Bu durum ve bazı nüshalarının Edviye-i Müfrede ile bir arada ciltlenmesi onun başka yazarlara mal edilmesine de neden olmuştur. Eser üzerinde Önler, doktora tezi (Önler, 1981) yapmıştır. Ayrıca eser, kitap (Önler, 1990) olarak da yayımlanmıştır. Çalışmadaki örnekler için bu kitap kullanılmıştır.

Müfíd (Nazmü't-Teshîl) (M): 15. Yüzyllda (1467) yazılmış bir tıp kitabıdır. Yazarın müellifi Muyîddin Mehî’dir. Eser Sabuncuoğlu Şerafettin tarafından istinsah edilmiştir. Eser, tıp metinlerinin Türkçe yazılma gayretlerinin bir örneğidir. Kaya tarafından üzerinde bir doktora tezi yapılmıştır. Yükümlülük kipliği ile ilgili örnek cümleler bu tezden elde edilmiştir (Kaya, 2008).

Mecmaü'l-Mücerrebât (MM): Mecmaü'l-Mücerrebât adlı eser, bir çeviri eserdir. Ahmed bin Bâlî tarafından 16. yüzyılda Eski Anadolu Türkçesiyle çevrilmiştir. Eser, halkın okuyup istifade edebilmesi için sade bir dille yazılmıştır ve bu yüzden de Türkçe dil çalışmaları için önemli bir tıp kitabıdır. Mecmaü’l-Mücerrebât adlı çeviriyi Kartal, yüksek lisans tezi olarak incelemiştir. Çalışma malzemeleri için yararlanılacak eser örnekleri bu tezden alınmıştır (Kartal, 2016).

Kitâb-ı Tercüme-i Tezkkire-i Dâvûd Fz İlmi't-Tıbb (KTTD): Dâvûd-ı Antakî’nin Tezkiretü Uli'lElbâb ve'l-Camiü'l-Acebü'l-Ucab adlı eserinin ilaçlarla ilgili bölümü, Muhammed bin Mustafa El-Gûrânî tarafından Kitâb-ı Tercüme-i Težkire-i Dâvûd Fi İlmi’t-Tıbb adıyla çevrilmiştir. Çeviri 1642 yllında tamamlanmıştır. Eser üzerine bir doktora tezi bulunmaktadır. Çalışmanın verileri bu tezden alınacaktır (Arslan, 2014).

Kenzü's-Sıhhatü'l-Ebdâniyye Eser-i Mürşid-i Osmaniyye (KSE): Eser, 19. yüzyllda yani 1881'de Osman Hayri Mürşid Efendi tarafından yazılmıştır. Eser üzerinde Telli, bir doktora tezi hazırlamıştır (Telli, 2017). Çalışmanın malzemeleri bu tezden alınmıştır.

Terceme-i Akrâbâdîn (TA): II. Bayezid’in Amasya'ya vali olarak gönderildiği 1454 yılında yazıldığı tahmin edilen bu eser, Cürcânî lakabıyla tanınan büyük İslâm hekimlerinden Zeyneddin Ebu'l-Fazl İsmail bin Hüseyin Cürcânî’nin Zahîre-i Harzemşâhî adlı Farsça Akrabâdîn kısmının tercümesidir. Eser üzerine Doğan (Doğan, 2009) doktora tezi hazırlamıştır. Çalışma verileri için bu tezden yararlanılmıştır.

\section{Kavramsal çerçeve}

\subsection{Yükümlülüik kipliği}

Türkçe Sözlük’te “yükümlülük, yapılması zorunlu olan iş veya bir işi yapma zorunluluğu, yükümlülük, yüküm, mükellefiyet, mecburluk, mecburiyet” (Türkçe Sözlük, 2011: 2625) olarak tanımlanmaktadır. Yükümlülük kipliği, kiplik mantığındaki kiplik çeşitlerinden biridir ve o bu disiplinde deontik kiplik olarak adlandırılmaktadır. Yunanca kökenli bir kökten gelen deontik kelimesi, ödev anlamına gelir. Kiplik mantığının alt disiplinlerinden biri olan deontik/yükümlülük mantığını Çetres Kutlusoy'dan şu şekilde aktarmaktadır:

“... iyi, kötü, ödev/yükümlülük, gereklilik, özgürlük, sorumluluk, buyruk, izin, istek/dilek, yasak gibi ahlak felsefesinin temel kavramlarına ve bunlarla bağıntıl nosyonlara ilişkin mantıksal ilkelerin örneğin, ahlaksal ödev ve ahlaksal yasa(klı) ğın birlikte olanaksızlığının vurgulandığı ilke gibi ahlak 
felsefesinin mantıksal ilkelerinin- formel bir sistem içinde formülleştirilmesidir” (akt. Çetres, 2014: 36).

Dil bilimsel kiplik çalışmalarındaki yükümlülük kipliği ise genellikle izin ve zorunluluk ile ilişkilendirilen bir kiplik çeşididir. Burada, onunla ilgili açıklamalar, ağırlıklı olarak alan yazınının önemli isimlerinin görüşleriyle yapılacaktır.

Kratzer'e göre yükümlülük kipliği, geleneksel olarak izin ve zorunlulukla ilişkilendirilir ve bir ifadede yer alan durumların ahlakî olarak makbullük (moral desirability) derecesine işaret eder. Bu kavram, tam anlamıyla bireysel sorumluluklara yönelik kişisel etik kriterler ve sosyal normlarla ilgilidir. Mesela bir gangsterin yaptıklarının olumlu veya olumsuz olarak değerlendirilmesi/görülmesi bu kriter ve normlarla olabilmektedir. Etik kriterler ve sosyal normların ifade edilmesindeki yollar, yükümlülük kipliğinin işaretleyicilerini de çeşitlendirmektedir (Kratzer, 1981: 111). Ahlaki terimi ise, yükümlülük kipliğinde, değerlerle ilgili güçlü kişisel normlardan sosyal prensipleri içine alan her türlü yaptırımlar için kısa kullanım amacıyla tercih edilen bir ibaredir (Nuyts-Byloo-Diepeveen, 2005, 8).

Narrog'a göre yükümlülük kipliği, bir önermenin, sosyal kurallar (social rules) çatısı altında olası (possible) ya da zorunlu8 (necessary) olarak işaretlenmesidir. Yükümlülük ve bilgi (ve aletik) kipliklerinin alan yazınında iyi bilinmesine ve geniş bir şekilde kabul görmesine karşılık, onların doğal dildeki kipsel ifadelerin hepsini karşıladığı, ele aldığı söylenemez. Prensipte, kipliğin, anlam bilimsel olarak, onu çözümlemeye çalışanın anlam bilimsel ayrıntılarının derecesine göre sonsuz biçimde (ad infinitum) farklılaşabildiği söylenir. Ancak dildeki biçimsel ayrımlara denk gelmeyen anlam bilimsel ayrımların da kuşkulu değerler olduğu unutulmamalıdır (Narrog, 2012: 8).

Palmer'e göre gerçek/gerçekdışı kip ayrımıyla bulunmuş olan tüm kategoriler9 gibi kiplik de zor tasnif edilen bir kategoridir. Bu zorluğu baştan kabul ederek o, bir kiplik sınıflandırması yapmış ve yükümlülük kipliğini olay/eylem kipliği (event modality) içerisinde ele almıştır. Yine yükümlülük kipliğine kitabının çeşitli bölümlerinde yer vermiştir. Buna göre yükümlülük kipliği hem biçimsel ve kullanımsal örneklerle hem onların ilişkilendirildiği alt konular ve anlamlarla hem de gerçek/gerçek dışı ve bildirme/dilek (indicative and subjunctive) ikili ayrımları ile ele alınmıştır. Bunların her biri üzerinde çalışılan konuyu içermemektedir. Bundan dolayı onun yükümlülük kipliği ile ilgili değindiği noktalar konumuzla sınırlandırılarak ele alınmıştır. Bu çerçevede belirlenen söz konusu noktalar ise şunlardır: Yükümlülük kipliğinin özellikleri, onun alt anlamları veya ulamları, yükümlülük kipliğinin ilgili olduğu konular. Yükümlülük kipliğinin özellikleri: Palmer'e göre, yükümlülük kipliği dış kaynaklı (external sources) izin ve zorunluluklarla ilgili kipliktir.

Yükümlülük kipliğinde, genellikle ve sıklıkla, kurallar (rules), yasa/kanun (law) doğrultusunda alıcıya zorunluluk sıralayan ve izin veren gerçek/fiilî bir kişi/konuşucu (actual speaker) vardır.

Bir konuşur tarafından söylenmesine rağmen onun tamamen öznel olduğu söylenemez.

\footnotetext{
s Bize göre Türkçede necessary, necessity gereklilik; obligation, obligatory ise zorunluluk sözcüğü ile karşlanmalıdır. Ancak bu ikili ayrım Türkçede aygın olarak olasılık ve zorunluluk olarak çevrildiği için burada necessary, zorunluluk ile karşılanmıştır.

$9 \quad$ Kiplik dıșında gerçek dıșllıkla ișaretlenen ve coğunlukla kiple bulunabilen diğer önemli kategoriler, [sıfatlı șekillerin Türkçede yaygın karşılı̆̆ı olmadığı için bazı terimler isimmiş gibi düşünülerek çevrilmiştir] "gelecek (future), olumsuzluk (negative), soru (interrogative), emir-kibar buyurma (imperative "strong commands"-jussive "polite commands"), önceden varsaylmıs (presupposed), sart (conditional), amaç (? neden) ve sonuç (purposive and resultative); istekler "arzu, dilek ifadeleri” (wishes "desiderative”), korkular (fears “timitive”) ve geçmişteki alışkanlıklar (habitiual-past)"dır (Palmer, 2001: 22).
} 
Yükümlülük kipliği ile ilgili ifadelerde olay potansiyel olarak var olmasına rağmen henüz gerçekleşmemiş (not actualized)'tir.

Yükümlülük kipliğinde dış şartlar/kaynaklar konuyla ilgili olarak bir kişiyi harekete geçirmeyi, bir kişiye izin vermeyi veya zorunluluk bildirmeyi içerir.

Yükümlülük kipliğinde kişi bir izin ve zorunluluğu dış şartlara göre verir ve bundan dolayı bunu dinleyen kişi kendisine söylenilen zorunluluktan veya izin vermemeden dolayı kırılmaz ve gücenmez. Aksi takdirde dinleyici, konuşucunun mağrur, küstah olduğunu düşünürek gücenir, kırılır ve alınırdı. Yükümlülük kipliğinin alt anlamları veya ulamları: Palmer, yükümlülük kipliği tasnifine "permissive, obligative ve commissive"i dâhil etmiştir. Bu kiplik anlamlar ve alt ulamlar ise, Türkçe kiplik çalışmalarında genellikle izin, zorunluluk ve emir ile karşılanmaktadır. Bunlardan emir sözcüğünün commissive'i ne kadar karşıladığına konusunda emin olunamamaktadır'10. Ayrıca zorunluluk ifadesi de obligative için mümkün karşllıklardan olsa da bununla gereklilik arasındaki sınırın hem Palmer de hem de Türkçe çevirilerde yeterince belirli olmadığı düşünülmektedir. İster istemez akla şu sorular gelir: Zorunluluk, gerekliliği kapsayacak bir anlama mı sahiptir?; Gereklilik mi zorunluluğu kapsar?; Gereklilik ve zorunluluk farklı kavramlarsa bunların yükümlülük kipliği içerisinde ayrı ayrı ele alınması gerekmez miydi?; Eğer gereklilik ve zorunluluğun ikisi de aynı alanı içeriyorsa o halde gereklilik veya zorunluluk nedir?; Gereklilik veya zorunluluk yalnızca kiplik alanlar açısından farklı, ama esas noktada bir midir? ve hatta Yükümlülük nedir?; Gereklilik Nedir? Bunların cevabı veya tartışmaları bu yazının konusu değildir, ancak ilginç bulunduğu için en azından sorularla bu konuya dikkat çekilmek istenmiştir. Yükümlülük kipliğinin ilgili olduğu konular: Palmer’in yükümlülük kipliği ile ilişkilendirdiği konuların birkaçı, direktifler, öznellik ve emir ve kibar buyurma (imperative "strong commands"-jussive "polite commands" ${ }^{11}$ 'lardır.

Palmer, Searle'den yaptığı alıntıyla yükümlülük kipliğinin en bilinen türlerinin "direktifler (directives)” yani "Bir şeyleri yapması için birilerini bulmaya uğraştığımız [ifadeler]" (aktran Palmer, 2001: 70) olduğunu söyler. Ona göre direktiflerin iki türü, İngilizcede may (konuşma diline özgü can) veya must ile yapılır. Bunlar da “izin (permissive) ve zorunluluk (obligative)”dur.

Palmer’e göre yükümlülük kipliği konuşurdan kaynaklı bir kipliktir. Onda, sıklıkla konuşmacıdan kaynaklı izin verme ve zorunluluk kullanılır, ama buna rağmen yükümlülük kipliğinin, daima öznel olduğu iddia edilemez: "You can smoke in here. [Burada sigara içebilirsiniz.]; You must take your shoes off when you enter the temple [Mabede girdiğinde ayakkabılarını çıarmalısın.]”.

10 $\quad$ Commissive’in İngilizceden İngilizceye karşılıkları şunlardır:

A speech act by which a commitment is made, such as a promise or threat; Making a commitment, such as a promise or threat, by illocutionary means (https://www.seslisozluk.net/de/was-bedeutet-commissive/); commitment da willingness to give your time_and energy to something that you believe in, or a promise or firm decision to do something; something that you must do or deal with that takes your time (https://dictionary.cambridge.org/dictionary/english/commitment); commission (request work) da to formally choose someone to do a special piece of work, or to formally ask for a special piece of work from someone (https://dictionary.cambridge.org/dictionary/english/commission).

Bu anlamlar şu şekilde çevrilebilir: Kendisiyle bir tehtit ya da söz verme gibi bir taahhüdün/vaatin/üstlenmenin yapıldığı konuşma eylemi, sözeylem; edimsel vasıtalarla, bir söz verme veya tehtit gibi bir taahhüt yapma (https://www.seslisozluk.net/de/was-bedeutet-commissive/); commitment, inandığınız bir şeye zamanınızı ve enerjinizi vermeye hevesli olma ya da bir șey yapmak için karar verme veya söz vermeye istekli olma; Zamanınızı alacak yapmanız ya da uğraşmanız gereken bir şey (https://dictionary.cambridge.org/dictionary/english/commitment); commission (talep etme/isteme işi) de işin özel bir parçasını yapacak birini resmi bir şekilde seçmek ya da birinden işin özel bir parçasını [yapmasını] resmi bir şekilde istemek (https://dictionary.cambridge.org/dictionary/english/commission).

Terimlerin açıklaması için Palmer'in imperative ve jussive açılamalarında geçen strong commands ve polite commands ifadelerinden yararlanılmıştır (Palmer, 2001: 181). 
Ayrıca zorunluluk (obligation) konusunda farklı bir durum vardır. Zorunluluk işareti olarak kullanılan birimler her zaman bir zorlayıcllı̆̆ ifade etmez. Örneğin İngilizcede must ve have to biçimlerinde bu örneklendirilebilir. Have to, Palmer'e göre konuşmacının herhangi bir sorumluluk almadığı ve must'a alternatif olan bir biçimdir. Must ise öneri (suggest) ve davet (inivation) bildirebilir. O, ikisi arasındaki zitlı̆̆ şu şekilde örneklendirir: "You must come and see me tomorrow [Yarın gelmelisin ve beni görmelisin]; You have to come and see me tomorrow [Yarın gelmek ve beni görmek zorundasın]”.

İlk cümlede bir öneri ve davet yer alır. İkinci cümledeki öneride ise konuşurdan bağımsız bir zorunluluk ve zorlayıcılık vardır. Eğer öyle olmasaydı dinleyici, konuşucunun mağrur, küstah olduğunu düşünürek gücenir, kırılır ve alınırdı. Bundan dolayı Palmer'e göre İngilizcedeki must, have to’ya göre daha özneldir.

Palmer'e göre dillerde emre (imperative) ayrılmış bölümler vardır. Bunlar kipsel sistemlerden (modal system) bağımsız olarak ele alınmıştır. Emir, kavramsal olarak açık bir şekilde bir buyruk içerdiği için direktiftir, gerçekleşmemiş olayları içerir ve bu yönleriyle yükümlülük kipliği ile ilişkilendirilebilir. Gerçekte de emir bir otoriden çıkan ve itaatsizliği, yerine getirilmemesi beklenilmeyen güçlü bir direktiftir. Ancak bununla birlikte her emir ifadesi yükümlülükle ilişkilendirilemez. Çünkü emir, güçlü ve kibar buyrumlardan oluşur. Onun güçlü buyrumu yalnızca 2. şahıslarda vardır. 1. ve 3. şahıslarda ise güçlü bir emirden bahsedilemez. 1. ve 3. şahıslarda görülen emir ifadeleri ise bu sebeple kibar buyurma (polite commads)'lar olarak nitelendirilmelidir. (Palmer, 2001: 9-72).

Van der Auwera ve Plungian, kipliğin anlam bilimsel haritası çalışmalarında kipliği possibility (olanaklhlk) ve necessity (gereklilik) ${ }^{12}$ kavramları çerçevesinde ele aldıklarını açılamışlar ve bu ikili ayrımla da kiplik çeşitlerini katılımcı içi/katılımcı dışı kavramlara göre değerlendirdiklerini belirtmişlerdir. Buna göre yükümlülük kipliği, katılımcı dışı gereklilik ve olanaklılık kapsamında yer alır. Katılımcı dışı gereklilik ve olanaklılık yükümleyicilik yönüyle birbirleriyle ilişkilidirler. Van der Auwera ve Plungian'ın bu ayrımında ayrıca katılımcı dışı gereklilik içerisinde ele alınan yükümleyici gereklilik, obligation'a (zorunluluk); katılımcı dışı olanaklılık içerisinde ele alınan yükümleyici olanaklılığın ise permission’a (izin) denk geldiği parantez içi bilgisiyle verilmiştir. Bir başka ifadeyle onların katılımcı dışı gereklilik alanı gereklilik ve zorunluk'tan; katılımcı dışı olanaklılık alanı ise olanaklılık ve izinden oluşmaktadır. Palmer’in tersine yükümleyici gereklilik yani zorunluluk, gerekliliğin; yükümleyici olanaklılık yani izin ise olanaklılığın sınırları ve kapsamı içerisindedir. Palmer'de ise yükümlülük, zorunluluğu ve izni kapsar. Bu açıklamalardan da anlaşıldığı üzere, van der Auwera ve Plungian (Auwera-Plungian, 1998)'da, dışsal unsurlara ve şartlara sahip olan yükümlülük kipliği ise gereklilik ve olanaklılığın sınırları içerisinde yer alır ve onların birbirleriyle yükümlülük yönünden kesiştikleri alanı belirtir.

Erk Emeksiz’e göre yükümlülük kipliği Wynmann'dan aktarımla, "bir eylemin bir otorite tarafından görevli kılınan kişilerin uygulaması beklenen eylemlerin olasılığı ve gerekliliği ile ilgilenen” yükümlülük kipliğinin kaynağı, bu otorite, kişiler, ahlakî değerler, toplumun ve dinin belirlediği ilkeler (Erk Emeksiz, 2008: 56)'dir.

Araştırmacılarda bazen yükümlülük kipliği alt ulamı (Palmer, 2001) bazen de yükümlülük kipliğini kapsayan bir kiplik alanı olarak (van der Auwera-Plungian 1998), ele alınan gereklilik ve zorunluluk

Bu sözcüklerin Türkçede farklı araştırmacılarda farklı karşılandığı gözlemlenmiştir. Burada van der Auwera ve Plungian
(Auwera-Plungian, 1998)'ın kipliğin anlam bilimsel haritasında geçen terimler için Rentzsch (Rentzsch, 2013)'in verdiği karşıllklar, tercih edilmiştir. 
kipsel anlamları, Papafragou'da (Papafragou, 2000) kipsel alanlarla açıklanmaya çalışılmıştır. Onun bu konudaki görüşlerinin de çalışmayla ilişkilendirilebileceği düşünülmektedir. Çünkü yükümlülükle ilgili olan bu kavramlardaki kipsel ayrım noktaları çalışma konumuz için de önemlidir. Bundan dolayı buraya alınmıştır. Başa dönecek olursak Papafragou'da gereklilik ve zorunluluk kipsel alanı ve bazı durumlarda kipsel alt anlamları, bu anlamlara etki eden kipsel alanlarla ele alınmıştır. Papafragou (Papafragou, 2000), her kiplik belirtisi ve birimi için farklı kipsel alan ve kısıtlayıcıların olduğunu, bunların da kiplik belirtilerinin ve birimlerinin farklı kullanımlarında etkin olduğunu savunur. Ona göre yaptırımı olan bir gücün, kılıcının istendik bir davranışı/eylemi gerçekleştirmesini sağlaması zorunluluktur. Kılıcı üzerindeki bu yaptırım "olağan, düzenleyici, inanca, isteğe ya da önermelerin yorumuna dayalı kipsel alanlar yani düzenleyiciler (örn. yasa, yasak, kanun, kural, otorite), inanca dayalı alanlar (günah, dini kural), sosyal alanlar (toplumsal yaptırım, ayıp, gelenek-görenek)"ler zorunluluk tanımlayabilir. Zorunluluğa göre daha güçsüz bir yaptırımın geçerli olduğu durumları tanımlayan gereklilik ise "idealmerkezli alanlar (ideal-centered domains), olağan merkezli alanlar (normative domains), kişisel inanç ve görüşler ile istekler"de ortaya çlkar. Bunlar şu şekilde örneklendirilebilir:

Zorunluluk kipsel alanları ve onlarla ilgili örnekler:

Satrançta oyuna başlarken her oyuncu bir piyonunu oynamalıdır. (kural)

Bir Müslüman oruç ibadetine başlamak için niyet ederek oruç tutmaya başlayınca artık onu tamamlamalıdır. (dini kural)

Kırmızı ışıkta durmalısın. (kanun)

Yarın Ankara'da olmalısın. (otoritenin dayattığı yaptırım)

[Milli eğitim yönetmeliğinde der ki:] Her gün düzenli plan yapılmalı. (kural + yasa)...

Gereklilik kipsel alanları ve onlarla ilgili örnekler:

Kars Valiliği ve Belediye Başkanlığı, Metzamor'un kapatılması için uluslararası düzeyde girişimde bulunmalı ve Avrupa İnsan Hakları Mahkemesi'ne (AİHM) gitmeli. (ideal-merkezli + kişisel inanç)

Siz tertemiz giyiminizle, konuşmanızla onlara moral ve güven vermelisiniz. (ideal merkezli + kişisel inanç)

Sabiha Gökçen, havacılık literatüründe yer almıyor. Oysa, onu tüm dünya tanımalı. (kişisel görüş).

Bu filmi mutlaka görmelisin. (kişisel inanç ve istek)

Görmediyseniz mutlaka görmelisiniz. Hatta bununla yetinmemeli, Mersin'den Antalya'ya kadar gündüz gözüyle otobüsle yolculuk yapmalısınız. (kişisel inanç ve istek)

Kendinizi dinlemeli ve bunu mümkün olduğunca tarafsız, kendinizi korumadan yapmaya çalışmalısınız (kişisel inanç ve istek)

Yarın çok güzel olmalıyım anne, Güneş yanımda sönük kalmalı... (istek)

Pembe panjurlu, bahçeli bir evimiz olmalı. Çocuklarımız evimizin bahçesinde oynamalı. (istek) (aktaran ve örnekler veren (Corcu Gül, 2005: 5-9).

Özetlersek, zorunluluk, yaptırımı daha kuvvetli olan bir kipsel anlamdır ve gerçekle örtüşme olasıllı̆ı yüksektir. Gereklilik ise yaptırımı daha güçsüz ve gerçekle örtüşme olasıllğı daha zayıftır.

Bilindiği gibi Bybee-Perkins-Pagliuca (Bybee-Perkins-Pagliuca, 1994: 175-179), kipliği, eyleyici ve konuşur odaklı (agent-oriented modality ve speaker-oriented modality) olarak ele almıştır. Onlar, eyleyici odaklı kiplik içerisine "obligation, necessity, ability, desire ve root possibility”yi dâhil etmişlerdir. Bunlar çalışmada sırasıyla zorunluluk, gereklilik, yetenek, istek ve kök olasıllk sözleriyle karşllanmıştır. Zorunluluk ve gereklilik, yükümlülük kipliği ile ilişkilendirilen kavramlardır. Çalışma 
konusu gereği burada Bybee-Perkins-Pagliuca (Bybee-Perkins-Pagliuca, 1994)'nın zorunluluk ve gereklilikle ilgili görüşlerine yer verilecektir. Onlara göre bir eylemin yapılması için eyleyiciyi zorlayan dış ve sosyal şartları bildiren zorunluluk, güçlü zorunluluk (İngilizceden bunu must'la örneklendirmiştir) ve zayıf zorunluluk (İngilizceden bunu shouldla örneklendirmiştir) olarak ikiye ayrılır. Gereklilik ise bir eylemin yapılması için eyleyiciyi zorlayan fiziksel/bedensel/içsel şartları bildirir. Bunu da onlar İngilizcede need ile örneklendirmişlerdir. Konuşur odaklı kiplikte ise "imperative (emir/yalnızca 2. şahıs), prohibitive (yasaklama/negatif buyruk), hortative (yüreklendirme), permission (izin), admonitive (nasihat/uyarı), optative (istek)" yer alır. Bunlardan da emir, yasaklama, nasihat/uyarı, izin çalışmanın konusu olan yükümlülük kipliği ile ilişkilendirilebilir. Onların görüşlerinden yola çıkarak yükümlülük kipliği ile ilgili düşünceleri toparlanırsa;

Yükümlülük kipliğinin gereklilik ve zorunluluk yönüyle eyleyci odaklı olduğu yani bu ifadelerde yer alan yaptırımların onları yapacak olanı ilgilendirdiği,

Yükümlülük kipliğinin izin verme, emretme, yasak koyma, nasihat/uyarı yönlerinden konuşan tarafindan ifade edildiği (ki buna gereklilik ve zorunluluk da eklenebilir),

Yükümlülük kipliğinin zorunluluk boyutuyla sosyal, gereklilik boyutuyla da içsel şartları olduğu elde edilir.

\subsection{Tıp metinleri ve klasik Türkçe tıp metinleri}

Metin kelimesi, Türkçe Sözlük’te "Bir yazıyı biçim, anlatım ve noktalama özellikleriyle oluşturan kelimelerin bütünü, tekst ve basılı veya el yazması parça, tekst" (Türkçe Sözlük 2011: 1667) şeklinde açıllanmaktadır. Türkçe Sözlük’teki açılamalarda da görüleceği gibi bu sözcüğün Batı dillerindeki karşllığ Fransizcada texte ve İngilizcede text'tir. Sözcüklerin kökeni Latincede dokumak (weave) anlamına gelen textus sözcüğüdür ve sözlerin yapısal ve semantik olarak iç içe geçmesini anlatır (Akbayır, 2004: 11). Dil birimlerinin yapısal ve semantik olarak iç içe geçme özelliği, metin teriminin tanımlarında da görülmektedir¹3 (https://glossary.sil.org/term/text;_Aksan-Aksan, 1991: 98-100).

Biber'e göre tıp metinleri, bilimsel ve öğretici metinlerdir. Aynı zamanda onda ikna edici özellikler, edebî metinlere göre daha fazladır. Onun ikna edici özelliğinde elbette bilimsel olmasının payı büyüktür (akt. Yarar, 2006: 4-14). Bu açıklamalar ışığında şunlar söylenebilir: Tip metinleri, öğretici ve bilimsel olduğu için, kişisel görüşlerden ziyade ilaç yapımları, kullanımları, hastalık teşhisleri ve onların tedavileri noktasında kişiden kişiye değişmeyen, nesnel bilgilerle donatılmıştır. Bundan dolayı hekim görüşlerini tanıklayıcı verilerle sunmaya çalışır. Bir tedavi önermek veya bir ilacı kullandırmak ve hatta ameliyat olmak için dili ikna edici olarak kullanmak zorundadır. Çünkü hasta somut veriler olmadan kendi hayatını tehlikeye atmak istemez ve tedavideki sıkıntıları göğüslemeye razı olmaz ${ }^{14}$. Hekimlerin yaptırım

\footnotetext{
13 Metin'le ilgili farklı tanımlamalar ve detaylı bilgi için bk. (Aksan-Aksan, 1991).

14 Basım aşamasında olan bir çalışmamızda geçen bir tedavi ilginç bulunduğu için ve hekimlerin ikna edicilik boyutunu göstermek amaciyla buraya alınmak istenmiştir:

(10a) 11) ... kimseniñ beli ağrısına yāhūu 12) belinden aşaġı dutmasa żızı olsa 13) ziyādesiyle ağrısa feryād itse dermān (1ob) 1) bulınmasa imdi ḳurdıñ leşini bulup meselā 2) kemiklerin cümle mevcūd ola andan șoñra vā-3)-fir āteş yaḳup temām kurd [d]üşe andan 4) götürüp ķurduñ kemükleriñ yanmış ḳor 5) üzerine ata ḳor üzerine üç karış 6) yüksekligi bir hayvān idüp ol hastayı anıñ 7) üzerinde yatura bir hoş üzerine ortursa ol kemü-8)-kler yanınca ķokusından ziyāde bugulansa 9) gerek hemān ziyāde șabr itsün inşā'allāhü 10) günden güne defè ola ḳalḳa bi-izni'l-lāhi 11) te 'āla (Kitāb Eczāi Lokmān Hekìm, Vatikan Türkçe Eserler 430).

ifadelerinde de görüldüğü gibi hekim söylememiş olsa kim kemiklerinin tamamı yerli yerinde olan kurt leşi arar ve de onun kemiklerinin tütsü ile (ve hatta leş kokusu ile) dolu gölgelik şeklindeki kapalı bir mekanda kalabilir?
} 
güçlerinin temelinde de bunun yattığı söylenebilir. Çünkü hekimler, hastalıklar ve ilaçlar konusunda hastalardan daha fazla bilgilere sahip olduklarına inanılan kişilerdir.

Klasik Türkçe tıp metinleri, Osmanlı Dönemi içerisinde yazılmış eserler içerisinde önemli bir hacim (Yaklaşık 4000 adet (İhsanoğlu-Şeşen vd, 2008: CIII-CVI)) oluşturmaktadır. Onlar, çeşitli alanları içeren bilgi birikimleri kadar dil özellikleri ve söz varlığı yönünden de önemli kaynaklardır. Dil bilimindeki önemli çalışma alanlarından olan ve fiil kategorileriyle ilişkilendirilen kiplik çalışmaları için de tıp metinleri hasta-hekim ilişkileri yönüyle ayrıca önemlidir. Çünkü hekim, hasta için bilgilerine güvenilen ve alanla ilgili yönlendirmesine ihtiyaç hissedilen bir otorite konumundadır. Onun hastadan (veya sağlık personelinden) yapmasını istediği ilaç kullanma veya basit ilaç hazırlama teknikleriyle ilgili istekleri ile ilaç kullanmaya dair emir, uyarı, yasaklama içeren yaptırım tarzı ifadeleri kiplik çalışmaları için incelenmesi gereken bir konudur. Çünkü kiplik alanının özellikle yaygın olarak yükümlülük kipliği olarak adlandırılan (eyleyici odaklı kiplik, nesnel zorunluluk/öznel zorunluluk, katılımcı dışı gereklilik veya yükümleyen gereklilik gibi adları da vardır.) alanı için önemli malzemeler sunma özelliğine sahiptir. Bu yönü yükümlülük kipliğinin birini görevlendirme veya birinden bir şey isteme özelliği ile örtüşmektedir.

\section{4. İnceleme}

Çalışmanın inceleme bölümünde konu, iki aşama dâhilinde ele alınmıştır. İlk bölümde yükümlülük kipliğinin özellikleri ve kiplik anlamları, ikinci bölümde de onun kiplik alanları ele alınmış ve sözü edilen tıp metinlerinden örneklerle tanıklanmıştır.

İlk bölümde yükümlülük kipliğinin özellikleri, yükümlülük kipliği bölümünde anlatılan görüşlere göre (Görüsslerin hepsinin yükümlülük kipliği ile ilgili özdeş olarak bir anlamsal değeri belirlediği düşünülmüştür.) ortaya çlkarılmıştır. Yükümlülük kipliğinin kiplik anlamları ise yine bu görüşler temel alınarak belirlenmiş, ancak tıp metinlerinden alınan örneklerde tespit edilen kiplik anlamlar da çalışmaya dâhil edilmiştir. Daha sonra yükümlülük kipliğinin özellikleri de kiplik anlamları da tıp metinlerinden alınan örneklerle tanıklanmaya çalışılmıştır.

İkinci aşamada yükümlülük kipliği, kiplik alanları özellikle Papafragou’nun (Papafragou, 200o) gereklilik ve zorunluluk kiplik alanı ile ilgili dile getirdiği görüşleriyle birlikte Nuyts-Byloo-Diepeveen, Kratzer'in fikirleriyle belirlenmiş ve bunların içerisinde tıp metinlerinin yeri tartışılmıştır. Bunlar aşağıda sırasıyla ele alınmıştır (Nuyts-Byloo-Diepeveen, 2005; Kratzer, 1981).

\section{1. Yükümlülük kipliğinin anlam belirleyicileri ve kiplik anlamları}

\subsubsection{Yükümlülük kipliğinin anlam belirleyicileri}

Yükümlülük kipliğinin anlamsal özellikleri, Palmer, van der Auwera-Plungian, Erk Emeksiz, Corcu Gül, Kratzer, Bybee-Perkins-Pagliuca ve Nuyts-Byloo-Diepeveen'in görüşleri doğrultusunda belirlenmiştir (bk. Yükümlülük kipliği). Bu görüşlerin yükümlülük kipliğinin bir özelliğini belirttiği, düşünülmüştür. Bundan dolayı görüşler, yükümlülük kipliğinin anlamsal özellikleri noktasında özdeş bulunmuş ve yükümlülük kipliğinin anlamsal özellikleri olarak değerlendirilmiştir. Bu görüşlere göre yükümlülük kipliğinin anlamsal özellikleri aşağıdaki gibi belirlenmiştir (Palmer, 2001; van der Auwera-Plungian, 1998; Erk Emeksiz, 2008; Corcu Gül, 2005; Kratzer, 1981; Bybee-Perkins-Pagliuca, 1994; Nuyts-BylooDiepeveen, 2005). 
Yükümlülük kipliği:
[+Zorunluluk bildirir.];
[+Gereklilik bildirir.];
[+İzin verir.];
[+Dile getiren yönünden konuşur odaklıdır.];
[+İşin yapılması yönünden eyleyici odaklıdır.];
[+ Söylenilen konuşuru değil; dinleyeni sorumlu tutar.];
[+Yapılacak iş için bir kişiyi/kişileri görevlendirir yani direktiftir.]
[+Konuşur odaklı olsa da tamamen öznel değildir.]
[+İfadelerinde olay potansiyel olarak var olmasına rağmen henüz gerçekleşmemiş (not actualized)'tir.]

Yükümlülük kipliği ile ilgili ifade edilen özelliklerden [+İşin yapılması yönünden eyleyici odaklıdır] ve [+ Söylenilen konuşuru değil; dinleyeni sorumlu tutar.] özelliklerinin özellikle 1. çoğul kişide (yapmalıyız; yapmak zorundayız gibi ifadelerde) tartışılabilir olacağı düşünülmektedir. Ancak burada bu durum tartışılmayacak ve bunlar yükümlülük kipliğinin bir özelliği gibi değerlendirilecektir. Buna karşılık yükümlülük kipliği özelliklerinde geçen gereklilik, izin ve zorunluluk kavramlarının çalışmada nasıl ele alındığının açılanması gerekmektedir.

Bilindiği gibi yükümlülük kipliği, zorunluluk, gereklilik ve izin'le birlikte ele alınmaktadır. Palmer'de (Palmer, 2001) bu anlamlardan izin ve zorunluluk, yükümlülük kipliği altında değerlendirilmiş ve zorunluluk ve gereklilik sınırı çizilmemiştir. Ancak onun yükümlülükle ilgili kavramlardan direktifleri açlklarken must ve have to ayrımında dile getirdiği görüşünün bununla ilişkilendirilebileceği düşünülmektedir. Palmer'e göre have to, kişinin kendisinden kaynaklanmayan must kişisel çıkarım ve görüşlerden kaynaklanan gerekliliği anlatmaktadır. Buna karşın van der Auwera ve Plungian'ın yükümlülük kipliğini değerlendirişi Palmer’inkinden farklllık göstermektedir (van der AuweraPlungian, 1998). Onlar, kiplikle ilgili, iki temel alanı (gereklilik (necessity) ve olanakllllk ${ }^{15}$ (possibility)) esas almışlar ve gereklilik alanına deontik/yükümleyen gerekliliği; olanaklılık alanına da deontik/yükümleyen olanaklllı̆̆ı dâhil etmişlerdir. Onlara göre deontik/yükümleyen gereklilik, obligation yani zorunluluk; deontik/yükümleyen olanaklılık ise permission yani izin'dir. Anlaşlacağı üzere onlar yükümlülüğü, yükümleyen (deontik) gereklilik ve olanaklılık olarak değerlendirmişler ve olanaklılık ve gerekliliğin ortaklaştığı, kesiştiği yerler olarak görmüşlerdir. İşte onların bu düşünceleri çalışmanın temel kavramlarının şekillenmesinde yani, izin, zorunluluk ve gerekliliğin çalışmada nasıl kullanılacağını belirlenmesinde rol oynamıştır. Buna göre konuşurun bildirdiği bir iş veya bir sorumluluk ahlakî veya yasa doğrultusunda olur ve bu konuda biri yükümlenirse bu ifadeler/cümleler, zorunluluk yani deontik/yükümleyen gereklilik olarak değerlendirilmiştir. Aksi durumdakiler ise gereklilik olarak ele alınmıştır ${ }^{16}$. Olanaklılığın yine doğrudan birine yönelik olması durumu ise izin, sayılmıştır. Örneklendirmek gerekirse,

Ankara’ya gitmek için trene binmek lazım.

Ankara'ya gitmek için uçak yok, otobüse binmelisin

İçeri girebilirsin.

\footnotetext{
15 Possibility ve necessity sözcüklerin farklı çalışmalarda farklı karşılıklarla geçtiği bilinmektedir. Burada Rentzsch’in tercihi ve çevirisinden yararlanılmıştır yani possibility, olanaklılık; necessity de gereklilik ile karşılanmıştır.

16 Bu açıklamalarda onların örneklerinden yola çıkılarak yapılan şahsî yorumlar da bulunmaktadır.
} 
Van der Auwera ve Plungian'a göre ilk cümlede kişiyi doğrudan sorumlu tutmayan ama kipliğe katılan şartlar açısından katılımcı dışılığı bildiren gereklilik vardır (van der Auwera-Plungian, 1998). Buna karşıllk ikinci cümlede ise otobüse binilmesi konusunda kişiyi yükümleme yani zorunluluk söz konusudur. Sonuncu cümlede ise bir işin yapılması noktasında birisine izin verilmiştir. Bu noktaya Palmer, emir ile ilgili açıklamalarda değinmiştir (Palmer, 2001: 9-72). Ona göre yükümlülükle ilgili olan emrin, yükümleyici anlamı, direktiflerdendir ve yalnızca 2. şahıslarda ortaya çıkar. Diğer şahıslarda kibar buyruk (jussisive) vardır.

Papafragou'da geçen gereklilik ve zorunluluk anlamının anlam alanlarına göre ideallik, olağanlık ve kişisellik bildirmesi, zorunluluğun ise daha güçlü bir yaptırım içeren düzenleyicilik, sosyal alanlar, inanca dayalılık görüşü yükümlülük kipliğinin anlamsal özellikleri ve alt ulamları/anlamları’nda dâhil edilmeyecek, bunlar ayrıca kiplik alanlar ile ilgili bölümde tartışlacaktır.

Bu doğrultuda tespit edilen yükümlülük kipliği anlamsal özellikleri, sözü edilen tıp metinlerinden alınan örneklerle aşağıdaki gibi incelenmiştir:

\section{Yükümlülük kipliği +zorunluluk bildirir.}

Tıp metinlerinden yükümlülük kipliğinin zorunluluk bildirdiği örneklenebilmektedir. Bunların, genellikle istek ve emir kipi 2. şahısta (Çoğulu örneklenememiştir.) ve cümlede, öznenin belirtildiği 3. şahıslarda ortaya çıktı̆̆ gözlenmiştir:

Bu büzūrī vü uṣūlī iskencübīn/Neyile bişmek gerekdür añlag̉ıll-Balıla yāḩūd şekerle didiler bişmek gerek/ Lìk balıla dimişler bişmegi [hem] yigirek (M, 47a/14-15)

Bozarıcak sıkasın u yine bir güli dahı ol suyıla kaynadasın/Ol șuyıla ḳaynadasın şöyle kim evvel ahı $(\mathrm{M}, 48 \mathrm{~b} / 7)$

Āb-zende oturmaḳ eyüdür yāhūd țatlu ḳavun yeye ifrāṭla ve bu illetüñ sāhibi fistuk ve çitlemük ve kavun çekirdegi içi șekerile yemek mülāzım ola (MM, 122a/1-3)

İlk örnekte görüldüğü gibi ilacın doğru olarak hazırlanabilmesi için pişirme tekniğinin iyice anlaşılması gerekir. Çünkü ilacın nasıl pişirilmesi gerektiği önemlidir. Böyle yapılırsa bulunması zor olan veya değerli malzemelerle hazırlanabilen ilaçlar boşa gitmeyecek ve istenilen vakitte istenilen etkiyi gösterebilecektir. Bu yüzden kişi emir 2. şahısla doğrudan görevlendirilmiştir. Bu kiplik anlam, gerek sözcüğüne gelen -dür koşacı ile de kuvvetlendirilmiştir. İkinci cümlede istek çekimi 2. şahısla kişi, ilaç malzemesinin ne zaman sıkılacağı konusunda doğrudan görevlendirilmiştir. Diğer örnekte ise kavun çekirdegi yemesi gerereken, bu illetün șâhibi olan öznedir. Bundan dolayı yapılması istenilen iş için görevlendirilen kişi bellidir ve ne yapması konusunda doğrudan görevlendirilmiştir.

Bu kiplik anlamı aktaran diğer örnekler:

Veremi ḳaṭı ola ve nefesi yatlu ola ve yatlu fikirler ḳla ve yüzinüñ ve gözlerinüñ rengi ḳarasagu ola 'ilācı budur ki rāzyāne șuyı ve kerefs șuyı ve hıyārșenber katup içüreler (MŞ, M76a/10-13)

zahīre-i harzemişāhuñ mușannifi eydür kitāb-ı ḳānūnda buncılayındur ki beyān ètdük ammā şöyle gerek gelür kim bu nusḩada ḳırfa yẻrine kebābe èdeler üç dirhem ḩavlıncān ziyāde ėdeler (TA, 93a/69)

șafrāvīden artuğınuñ 'ilācı evvel ḥuḳne-i mutavassıṭa eylemek ṣoñra ḥuḳne-i hạādde eylemek çoḳ olur ki evvel hukneyi eyleyicek ağrı artar korkmak gerek ve tezcek ikileyin hukne eylemek gerek ki bu maraza becib ḥuḳne eylemekden artuḳ çare yokdur (MŞ, M89a/ 11-15)

Pes imdi cimā' cism șeḳāletin gidermegiçün gerek, nefs ležzetiyçün gerekmez ya'nī șol vaktın gerekdür ki meni galebe ede (EM, 62a/14/15) 
Türbüd otuz biş direm maḥmūde on iki direm dögeler ve bu otları bișmiș ayva birle yugưralar, ma 'cūn eyleyeler (KA, 22b/7-8)

Kaçan ki ısıtma müddeti geçe lazımdır ki șayruya habbü’l-gaāfis vireler ve firik şorbasın yeye (EM, 56b/10-11)

Vācibdür ki idrara yardım edeler, kerefes ve rāzyāne șuyıyıla (EM, 56b/10-11)

Su 'd ve zīre her birinden ikişer dirhem kündür üç dirhem tohm-ı hurfe dört dirhem edviyyeleri dögüp eleyeler ve bu edviyyeler ḳadarı fānīd ḳatalar her șabāḥ bėş dirhem veyā yèdi dirhem isti māl èdeler (TA, 136b/12-17)

Omuz çıḳuġın yėrine ḳomasın beyān èder şöyle bilesin kim evvel gerekdür elüñile yapuşasın ve göñlüñile danıșasın göresin zikr ètdügümüz nişānları teşhīṣ ėdesin ḳanġısıdur aña göre işleyesin ve ol kişinüñ yaşını ve țabī'atını teşhīs èdesin andan işleyesin evvel çekmek budur omuz çıḳug̉ı yẻrine ḳomasın beyān ėder şöyle bilesin kim evvel gerekdür elüñile yapușasın ve göñlüñile danıșasın göresin zikr ètdügümüz nişānları teşhīṣ èdesin kanğısıdur aña göre ișleyesin ve ol kişinüñ yaşını ve tabī'atını teşhīs èdesin andan işleyesin evvel çekmek budur kim ol kişiyi yaturasın ol hasta yanını yoḳaru ḳoyasın ve bir țop ḥāzır ola böyüklügi şalgaam deñlü ola ve ḳuşag̉ı ol çıḳmış ḳolına bag̉layasın bir ucunı dirsekden yokaru ve bir ucunı ardına ve ol kușaġı kendü bẻlüñe geçüresin ve bir ḳușaḳ dahı bulasın ve ol ḳuşaġı da ol kişinüñ ḳoltuġı dibinden ve ol țopuñ üzerinden geçüresin (CM, 16a/13-15-16b/1-6)

\section{Yükümlülük kipliği +gereklilik içerir.}

Van der Auwera ve Plungian'ın kiplikle ilgili görüşlerini sunduğu kipliğin anlam bilimsel haritasında katılımcı dışı gereklilik, yükümlülük kipliğine katılan unsurların dıştan olması ve kişiyi doğrudan görevlendirmemesi özelliği ile ön plana çıkmaktadır (van der Auwera-Plungian, 1998). Bu özellikteki gerekliliği klasik Türkçe tıp metinlerinde yaygın olarak görmek mümkündür. Çünkü tıp metinlerinde ilacı hazırlayacak ve tedavi yöntemlerini uygulayacak kişilerin hastalar, halk hekimleri, hekimler olduğu düşünülse de bunların kim olduğu kesin olarak bilin(e)memektedir. Bu nedenle klasik Türkçe tıp metinlerinde gereklilik, genel olarak ifade edilmiş ve kişisiz (impersonality) olarak yani derin yapıda [+insan] gerektiren ama bunun belli olmadığı kişiler kullanılmıştır:

Bir mișkāl amma hep ḳavrulmış gerekdür (MM, 123b/2-3)

Ve ba ‘̇̀ı devālar ki ḥubūbdur meselā rāziyāne tohumı gibi pek dögmemek gerek mi dede ziyādece eglensün içün (GM, 26a/3-5)

Muḳluñ vezni ayāric eczālarınuñ birisi miḳdārınca gerekdür ve ba żı̀ kişiler șabırı yurlar issi mizāclu kişiler içün ammā yunmış șabıruñ ishāli az olur şol kişilerüñ kim ısıtmaları ḳatı olmaya vẻrseler revādur (TA, 88b/7-11)

İncelenen örnek cümlelerde yapılması gereken iş, bir kişiyi doğrudan yükümlememektedir. Cümlelerde pek dövmemenin, kavrulmanın ve hangi ölçüde kullanılacağının gerekliliği bildirilmektedir. Burada onu yapanı dolaylı bir şekilde yükümleyen ama işin gerekliliğini bildiren kiplik anlamlar bulunmaktadır.

Bu kiplik anlamı içeren diğer örnekler:

İki direm misk dahı kātạalar ki dahı kuvvetlü ola ayva yüz elli direm gerekdür ki bal od üstündeyiken kaynadup kefin alalar (MŞ, M97a/ 13-15).

Pes imdi cimā' cism sekāletin gidermegiçün gerek, nefs lezzetiyçün gerekmez ya nī şol vaḳtın gerekdür ki meni galebe ede (EM, 62a/14/15)

Bu ısıtmanuñ sebeb-i tevellüdi iki ḩılțdandur pes żarūretli anuñ 'ilācını dahı mürekkeb devālardan ètmek gerek iki hılțtandur pes 'ilācını mürekkeb devālardan ètmek gerekdür (TA, 8b/10-13)

Mukluñ vezni ayāric eczālarınuñ birisi mıkdārınca gerekdür (TA, 88b-7/8)

\section{Yükümlülük kipliği +izin verme anlamı taşır.}


Yükümlülük kipliği ile ilgili sıklıkla ifade edilen izin verme ve bunun olumsuzu olan izin vermeme özelliği, tıp metinlerininin konusu gereği metinlerinde oldukça çok sık karşılaşllan bir özelliktir. Bunların klasik Türkçe tıp metinlerinde genellikle istek ve emir kipi 3. şahıslar, öldür-, katl it-, yaramaz gibi sözlüksel unsurlarla ifade edildiği gözlenmiştir:

Her heftede mezkūr muḳayyiler-ile ḳay ideler ya nī ḳusalar (MM, 163b/16)

Bāderenbūya ıssıdur ḳurudur yaraḳāna müfìddür gāāịūn eger sikencübīn ḳațup içerlerse yarakāānı giderür ve eger ziyān ederse ılıcak șuyıla ḳuṣalar ve süd içeler (MŞ, 81b/15-82a/1-2)

İlk örnekte her hafta kay ideler yani ḳusalar ifadelerinde; ikinci cümlede de ilaç ham maddesinin zararının dokunması durumunda ılık suyla kusmaya ve süt içilmesine izin verildiği görülebilir.

Olumsuzlukla birlikte izin verilmeme anlamı da bulunmaktadır:

Ve eger bir şeyi ża îf olur ise hụụne olunmasun (KTTD, 104a/19)

Hem dimağı dahı arıdur velīkin iy cüvān/Var-durur andan baġarsuḳlara çoḳ ziyān (M, 52a/13)

ve ba ż̀ devālar ki ḥubūbdur meselā rāziyāne tohumı gibi pek dögmemek gerek mi dede ziyādece eglensün içün (GM, 26a/3-5)

Bu cümlede yaramaz, -dır, öldür-, istimal itmenüz kipsel unsurları ilacın kullanılmaması gerektiğini ve onun kullanımına izin verilmediğini anlatmaktadır. İkinci örnekte bagarsuklara çok ziyān'ı olduğu ifade edilen ilaç ham maddesinin kullanımına izin verilmeme söz konusudur. Bunun izin verilmeme olarak anlaşılmasına olumsuz anlamı olan ziyan kipsel sözcüğü ile çok kiplik zarfı etki etmiştir. Üçüncü cümlede -mAmAk gerek ifadesi, çok fazla dögülmeye izin vermeme anlamı işaretlemiştir. Bu özelliğiyle bu birim izin vermemeyle, yapmamak gerekliliği kesiştirmektedir.

Bu kiplik anlamla ilgili diğer örnekler:

mukluñ vezni ayāric eczālarınuñ birisi miḳdārınca gerekdür ve ba ‘̇̇ kișiler șabırı yurlar issi mizāclu kişiler içün ammā yunmış șabıruñ ishāli az olur șol kișilerüñ kim ısitmaları katı olmaya vèrseler revādur (TA, 88b/7-11)

Eger bādām yaġınuñ içine rūfiżūn yumurda sarusın çalkasalar gargara etseler gààyet eyüdür (MŞ, M64a/10-11)

Keyfiyyet-i mesirdīịtūs bu tiryāḳuñ ḥaḳkında naḳl vardur şeyh şedīd bin beyāndan bu tiryāḳuñ dahı ḥāli hemān tiryāḳ-ı fārūḳ gibidür keyfiyyet-i tiryāḳ-ı erba a bu tiryāḳuñ isti mālini cā'iz görmişlerdür tāzeligi vaḳtında ammā dört yıldan șoñra ḳuvveti bāṭll olur (TA, 271a/7-12)

Bu cevārīşi isti 'māl èden kiși kendüyi incidmeye (TA, 94b-13)

sünbül ve zirişk ['anberbārīs] ve gāais [koyunotı] ve kāsnī [hindibā] gibi ol otlar kim ziyānkārdur anları fā'idelü otlara ḳatmaynca isti māl ètmeyeler ve ba '̇̀̇ otlar vardur kim yürege fā'ide eyler

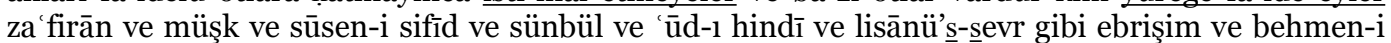
aḥmer ve behmen-i ebyaż gibi (TA, 11a/17-11b/1-7)

gāyet de nāfi 've mücerreb ve żararsız bulduk (GM, 54a/8)

Yükümlülük kipliği, +söyleyen açısından konuşur odaklıdır.

Yükümlülük kipliğinde, genellikle kurallar (rules), yasa/kanun (law) doğrultusunda alıcıya zorunluluk sıralayan ve izin veren gerçek/fiilî bir kişi/konuşucu (actual speaker) vardır (Palmer, 2001: 9-72). 
Bunlar, yükümlülük kipliğinin önemli bir özelliğidir. Yükümlülük kipliğinde konuşur, gerekeni, zorunluluğu ve izni ifade eden otoritedir. Bu yönden yükümlülük kipliği, konuşur odaklıdır. Tıp metinleri bu kullanımlar yönünden zengindir:

Bir şerbet vireler țlā ḳarnına bu yaḳuyı yaḳalar (KA, 25a/10)

Hem otuz altı direm toḩmını kāsnīnüñ girü/Yaru dögilmiş ola ḳaynadıban süzgil 'amū (M, 48a/1)

nercis yaġı gibi yaġlar-1la ovalar (MM, 125a/11-12)

ol yere hacamat urmaḳ gerekdür (MM, 125a/17)

Örnek cümlelerde yakuyı yakmayı, yarı dögmeyi, yaglar ile ovmayı konuşur, söyler, ama bunlar, konuşuru değil onu kullanacak veya uygulayacak olanı işaret etmektedir. Bir anlamda yükümlülük kipliğinde söz konusu olan ödev, yükümlülük yapanı ilgilendirmektedir.

Bu maddeyle ilgili diğer örnekler:

Og̉ul otu ve șa 'ter bunlardan birer ḳabża alup togigrayup kaynadup bir fincān üzerine içeler, șifā bula (KSE, 321/25-322/1-2)

(Aġac mürveri çiçeginden) bir ḳabża, ebegümeci yaprağından bir ḳabża alup kaynadup bir fincān üzerine içe (KSE, 323/1-2)

Ve perverde olmış zeytūnı ța āmdan öñdin pirler mizacına ... muvafikdır (EM, P58a/6-7)

\section{Yükümlülük kipliği +işin yapılması yönüyle eyleyici odaklıdır.}

Yükümlülük kipliğinde bildirilen iş, eyleyiciyi işaret etmektedir. Konuşur, işin yapılması konusunda işi yapacak olanı görevlendirir. Klasik Türkçe tıp metinlerinde de bununla ilgili örnekleri bulmak mümkündür:

üzümi șuyı birle baġı üstine ț̣lā eyleyeler (KA, 23b/7)

Gül ü benefşe şarabın nice itmek gerek/Bunları ḳaynadacaġaz az ḳaynatmek gerek (M, 48b/2)

Añul odıla güli yāhnūd benefşe'i ḥabīb/ḳaynadalar tā bozarınca bunları dir țabīb (M, 48b/3)

Tanık cümlelerde de fark edildiği gibi üzümü suyuyla tıla edecek, az kaynatması gerekecek, kaynatacak kişi konuşur değil onu uygulayacak, yerine getirecek kişidir.

Söz konusu maddeyle ilgili diğer örnekler:

Bu cevārīşi isti 'māl èden kişi kendüyi incidmeye (TA, 94b-13)

Eger bādām yaġınuñ içine rūfiżūn yumurda șarusın çalḳasalar gargiara etseler gāāyet eyüdür (MŞ, M64a/10-11)

Biraz yeseler öksürügi keser güyegü otını unıla balıla ḳaymaḳ eyleyüp yeyicek öksürüge nāfi dür (MŞ, $\mathrm{M} 71 \mathrm{a} / 15-\mathrm{M} 71 \mathrm{~b} / 1)$

(Aġac mürveri çiçeginden) bir ḳabża, ebegümeci yaprağından bir ḳabża alup ḳaynadup bir fincān üzerine içe (KSE, 323/1-2)

Yükümlülük kipliğinde +söylenilen konuşuru değil; dinleyeni sorumlu tutar.

Yükümlülük kipliğinde konuşur, işin nasıl yapılacağı konusunda da işin daha iyi nasıl olacağı konusunda da dinleyene göre daha bilgili, donanımlı ve otorite konumundadır. Bundan dolayı yükümlülük kipliğinde söylenilenler, karşıdakini, onu yapması konusunda sorumlu tutar. 
Klasik Türkçe tıp metinlerinde bu konuyla ilgili örneklere sık rastlanmaktadır:

ol ḳadar bal birle ḳaynadalar (KA, 26b/10)

ḳaynadıb șuyıla bişürüb dahı andan sıḳa/Şekkerile anı yāhūud balıla ḩoş-liḳā (M, 48a/15)

Yumşak dögeler ḥarīrden eleyeler (MM, 126b/5)

Vācibdür ki idrara yardım edeler, kerefes ve rāzyāne șuyıyıla (EM, 56b/10-11)

İlk cümlede yer alan ifade edilen bal ile kaynatacak kişi dinleyendir. Yine kaynadıp suyunu sıkacak, yumuşakça dövüp ipekten eleyecek ve kerefs ve raziyane suyuyla idrara yardım edecek de o işi yapacak kişi veya dinleyendir.

Diğer örnekler:

Su 'd ve zīre her birinden ikişer dirhem kündür üç dirhem toḩm-1 hurfe dört dirhem edviyyeleri dögüp eleyeler ve bu edviyyeler ḳadarı fānīd ḳatalar her șabāḥ bèş dirhem veyā yẻdi dirhem isti māl èdeler (TA, 136b/12-17)

omuz çıkugìn yẻrine komasın beyān èder şöyle bilesin kim evvel gerekdür elüñile yapușasın ve göñlüñile danıșasın göresin żikr ètdügümüz nişānları teş̧īṣ èdesin kanġısıdur aña göre ișleyesin ve ol kişinüñ yaşını ve tabīiatını teşhīs èdesin andan işleyesin evvel çekmek budur kim ol kişiyi yaturasın ol hasta yanını yokaru koyasın ve bir țop hāazır ola böyüklügi şalġam deñlü ola ve kuşaǵ̀ ol çıkmıș kolına bag̈layasın bir ucunı dirsekden yoḳaru ve bir ucunı ardına ve ol kuşaġı kendü bẻlüñe geçüresin ve bir kuşak dahı bulasın ve ol ḳuşaġı da ol kişinüñ koltuğı dibinden ve ol topuñ üzerinden geçüresin $(\mathrm{CM}, 16 \mathrm{a} / 15-16 \mathrm{~b} / 1-6)$

\section{Yükümlülük kipliğinde + konuşur(lar), yapılacak iş(ler) için bir kişiyi/kişileri görevlendirirler yani direktif verirler.}

Yükümlülük kipliğinde ifade edilen iş için kişi/kişiler görevlendirilir yani direktif verilir. Diğer bir ifadeyle konuşan, dinleyene görev vererek bir yönlendirme yapmış veya bir/yönerge ya da talimat vermiştir. Bunu yapan kişi aynı zamanda yapılacak işin nasıl yapılacağı konusunda da dinleyene göre daha fazla bilgi ve deneyim sahibidir. Klasik Türkçe tıp metinlerinden alınan aşağıdaki örneklerde bu durum incelenebilir:

șu birle yuguralar ve dört sā’at ḳadar ḳoyalar (KA, 47b/12-13)

Yüz direm dahı lisanü's $\underline{\text {-s }}$ evr șuyın alasız (M, 48a/3)

Diñlegil nice düzilür işbu haş̧̧̧aşdan şarāb (M, 48a/14)

ḳarha iḥdās ide hazer üzere isti 'māl gerekdür (MM, 125b/12)

Cümlelerde bildirilen işler, onu yapacakları yani hastaları veya hekimleri yönlendirmektedir. İlk cümlede su ile yoğurulması ve dört saat kadar bekletilmesi; ikinci cümlede lisanü's-sevr suyunun alınması; üçüncü cümlede haşhaş şarabının (veya şerbetinin) nasıl hazırlanacă̆ı; son cümlede de nasıl kullanılacă̆ konusunda talimatlar, yönlendirmeler vardır veya bunlara dikkat çekilmektedir.

Diğer örnekler:

ol kadar bal birle kaynadalar (KA, 26b/10)

ḳaynadıb șuyıla bişürüb dahı andan sıḳa/SSekkerile anı yāhūù balıla ḩoş-liḳā (M, 48a/15)

(Aġac mürveri çiçeginden) bir ḳabża, ebegümeci yaprağından bir ḳabża alup ḳaynadup bir fincān üzerine içe (KSE, 323/1-2) 


\section{Yükümlülükte + söylenilenler kurallar, yasalar, gelenek-görenekler çerçevesindeki doğrulardır yani nesneldir, kişinin keyfine bağlı değildir.}

Yükümlülük kipliğinde söz söyleyen, dinleyenleri yönlendiren otorite veya konuşan, özne olmasına, kişi olmasına rağmen onların söyledikleri, onların keyfi istekleri ve yaptırımları değildir. Onlar, dinleyeni herhangi bir görev için yönlendirirken kendi şahsının istediği özel istekleri değil, söyledikleri noktasında dış şartlardan, kullanılan maddelerin kendi özelliklerinden kaynaklı nesnel bilgileri ve görevlendirmeleri sunmaktadır. Tavsiye ettikleri de yine dinleyicinin iyiliğine ve çıkarına etki edecek özelliktedir. Klasik Türkçe tıp metinlerinde de hastalıklar konusunda uzman olan hekim veya eczacı, ilacın nasıl hazırlanacağı ve nasıl kullanılacağı konusunda şahsi düşüncelerini değil, ilaçlar ve hastalıklar konusundaki nesnel birikimlerini sunmaktadır. Daha açık bir ifadeyle yükümlülük kipliğinde kişi bir izin ve zorunluluğu dış şartlara göre verir ve bundan dolayı bunu dinleyen kişi kırılmaz, gücenmez. Aşağıdaki örneklerde bu özellikler belirlenebilir:

gerekdür kim ḳan alduralar (KA, 45b/5)

Yüz direm dahı lisanü's-sever șuyın alasız (M, 48a/3)

İlk cümlede hekim, kan aldırmanın gerekliliğine hastanın durumuna ve şartlara göre karar vermiştir yani kan aldırma kararı, hekimin keyfi ve öznel kararı değildir. İkinci cümlede de ilacın yapılması için lisanü's-sevr suyunun 100 dirhem olması gerekmektedir. Bu da ilaç yapım kuralı ile ilgili bir durumdan kaynaklıdır.

Diğer örnekler:

Kaçan ki ısıtma müddeti geçe lazımdır ki șayruya ḥabbü’l-gāfis vireler ve firik şorbasın yeye (EM, 56b/10-11)

Vācibdür ki idrara yardım edeler, kerefes ve rāzyāne șuyıyıla (EM, 56b/10-11)

Omuz çıḳugin yėrine ḳomasın beyān èder şöyle bilesin kim evvel gerekdür elüñile yapuşasın ve göñlüñile danışasın göresin zikr ètdügümüz nişānları teşhīṣ èdesin ḳanġısıdur aña göre işleyesin ve ol kişinüñ yaşını ve țabī'atını teşhīṣ èdesin andan işleyesin (CM, 16a/13-15-16b/1)

Ve ba żı̀ devālar ki huubūbdur meselā rāziyāne tohumı gibi pek dögmemek gerek mi dede ziyādece eglensün içün (GM, 26a/3-5)

\section{Yükümlülük kipliği ile ifadelerde + olay potansiyel olarak var olmasına rağmen henüz gerçekleşmemiş (not actualized)'tir.}

Yükümlülük kipliğinde bildirilen işin potansiyel olarak yapılması umulmaktadır ve hatta yapılması büyük oranda gereklidir. Bununla birlikte konuşma anında bu eylemin gerçekleştiği söylenemez. Çünkü yapılması istenilen iş konuşma anından ileriye dönüktür ve gerçekleşmemiştir.

İncelenen metinlerdeki yükümlülük ifadelerinde de bu özellik bulunmaktadır:

Biş gice peyāpey bu ḥuḳne’i eylemek gerek (KA, 48a/10)

Yaġlar-ıla bellerini ve bögürlerini muhkem ovalar (MM, 125a/10)

Bir yıldan tecāvüz eyleyeni yimesünler. (KTTD, 104b/3)

İlk cümlede bildirilen hukne eylemenmesinin gerekliliği henüz gerçekleşmemiştir. Yine yağlarla bellerin ve böğürlerin ovulması da tamamlanmış değildir. Görüldüğü gibi beş gece hukne eylenmesi ve muhkem ovma henüz gerçekleşmemiştir. 
Diğer örnekler:

Pes imdi cimā' cism sekāletin gidermegiçün gerek, nefs lezzetiyçün gerekmez ya'nī şol vaktın gerekdür ki meni galebe ede (EM, 62a/14/15)

Vācibdür ki idrara yardım edeler, kerefes ve rāzyāne șuyıyla (EM, 56b/10-11)

Omuz çıkugìn yẻrine komasın beyān ėder şöyle bilesin kim evvel gerekdür elüñile yapuşasın ve göñüñile danışasın göresin żikr ètdügümüz nişānları teşhịṣ ėdesin kanġısıdur aña göre işleyesin ve ol kişinüñ yaşını ve țabī'atını teşhīṣ èdesin andan işleyesin (CM, 16a/13-15-16b/1)

Mukluñ vezni ayāric eczālarınuñ birisi mıḳārınca gerekdür (TA, 88b-7/8)

Ve ba żı devālar ki hubūbdur meselā rāziyāne tohumı gibi pek dögmemek gerek mi dede ziyādece eglensün içün (GM, 26a/3-5)

Bāderenbūya ıssıdur ḳurudur yaraḳāna müfìddür gaāiīkūn eger sikencübīn ḳațup içerlerse yaraḳānı giderür ve eger ziyān ederse ılıcak șuylla kusalar ve süd içeler (MŞ, 81b/15-82a/1-2)

\subsubsection{Yükümlülük kipliğinin kiplik anlamları}

Dil bilimsel kiplik çalışmalarının bir boyutu da kiplik anlamlar veya kiplik alt ulamlardır. Ancak bu çalışmalarda kiplik anlamların bulunması konusunda ortak bir yöntemle inceleme yapıldığı söylenemez. Biz de bu çalışmada konu ile ilgili araştırmalarda yer alan yükümlülük kiplik anlamlarını, yalnızca olumluluk ve olumsuzluk ilişkisi ile ele almaya çalışacağız. Bu açıklamalar ve dil bilimsel kiplik çalışanlarınca ortaya konulan görüşler doğrultusunda yükümlülük kipliği kiplik anlamları aşağıdaki gibi belirlenmiştir:

\section{Gereklilik anlamı}

Klasik Türkçe tıp metinlerinde yükümlülük kipliğinin alt ulamı veya kiplik anlamı olarak ifade edilen gereklilik anlamı sıkça kullanılmaktadır. Çünkü Klasik Türkçe tıp metinleri, tabibin olmadığı yerlerde halkın kendini kolaylıkla tedavi edebilmesine yönelik olarak yazıldı̆̆ı için bir ilacın kullanımına yönelik genel bir gereklilik metinlerde daha yaygındır. Ayrıca bu kiplik anlam, olumsuzlukla birlikte (değil, mA-, yok gibi) gerekmezlik de ifade edebilir:

baselīkden faṣd gerekdür ve tafsilü'l- 'ilāc gerekdür (MM, 124b/15)

hār edviyyeler ve ḳavī müdirrler isti 'māl etmek lāzım degüldür (MM, 126b/5-6)

șoñra luṭf ile elesünler (KTTD, 66b/11)

ḳavī ve şedīd olmağla semmiyyetli devālar isti 'māl olunmamaḳ gerek (GM, 2b/15)

Bir mișkāl amma hep ḳavrulmış gerekdür (MM, 123b/2-3)

Ve ba 'żı devālar ki ḥubūbdur meselā rāziyāne tohumı gibi pek dögmemek gerek mi dede ziyādece eglensün içün (GM, 26a/3-5)

Mukluñ vezni ayāric eczālarınuñ birisi miḳdārınca gerekdür ve ba 'żı kişiler șabırı yurlar issi mizāclu kişiler içün ammā yunmış șabıruñ ishāli az olur şol kişilerüñ kim ısıtmaları ḳatı olmaya vẻrseler revādur (TA, 88b/7-11)

\section{Zorunluluk / yükümleyen gereklilik}

Çalışmada ele alınan zorunluluk, kişiyi doğrudan görevlendiren ifadelerde bulunmaktadır. Bunların klasik Türkçe tıp metinlerinde özellikle, emir ve istek 2. şahıslarda, öznenin doğrudan belirtildiği (barid olanlar, mizacı har olanlar gibi) durumlarda geçtiği gözlenmiştir. Bu ifadeler, olumsuzlukla birlikte eksi 
zorunluluk/zorunluluğun giderilmesi anlamı taşımaktadırlar. Klasik Türkçe tıp metinlerinde zorunluluğun olumlu ve olumsuz cümlelerde kullanımı ile belirlenen bazı örnekler aşağıdaki gibidir:

Ve maḥrūr olan sikencübīn içmek gerek (KTTD, 113b/6)

Ve ḳızll olanı demevī olanlar isti 'māl (17) eylemesün. (KTTD, 127b/16)

Ve istisḳāsı olan anıñ (20) yemesinden ḥazer itsün. (KTTD, 81a/20)

Türbüd otuz biş direm maḥmūde on iki direm dögeler ve bu otları bişmiş ayva birle yugưuralar, ma 'cūn eyleyeler (KA, 22b/7-8)

Kaçan ki ısıtma müddeti geçe lazımdır ki șayruya ḥabbü’l-ḡāfis vireler ve firik şorbasın yeye (EM, $56 \mathrm{~b} / 10-11)$

Vācibdür ki idrara yardım edeler, kerefes ve rāzyāne șuyıyıla (EM, 56b/10-11)

Su 'd ve zīre her birinden ikișer dirhem kündür üç dirhem tohm-ı hurfe dört dirhem edviyyeleri dögüp eleyeler ve bu edviyyeler ḳadarı fānīd ḳatalar her șabāh bẹş dirhem veyā yèdi dirhem isti māl èdeler (TA, 136b/12-17)

\section{Yasaklama}

Yükümlülük kipliğinin alt ulamlarından yani kiplik anlamlarından biri de yasaklamadır. Yasaklamanın olanaklılıkla (possibility), gerekliliğin (necessity) olumsuzlukta ortaklaştı̆̆ı söylenebilir. Ateşle oynama gibi bir cümlede ateşle oynanmasına izin verilmeme söz konusudur. Bu anlam aynı zamanda bir yasaklama da bildirmektedir. Bu yasaklama olanaklılıktan yani izin'den gelmektedir. Van der Auwera ve Plungian (van der Auwera-Plungian, 1998)'ın kipliğin anlam bilimsel haritasına göre izin, olanaklılık sınırları içerisinde yer alır ve yükümleyen olanaklılığa denk gelir. Ateşle oynanmasının yasaklanması gereklilik kiplik alanında da ifade edilebilir. Ateşle oynamayın gibi bir ifadede emir, gereklilik sınırları içerisindedir. Görüldüğü gibi gereklilik ve olanaklılık ifadelerinin, olumsuzlukla birlikte yasaklama anlamı kazanabileceği görülmektedir. Bu anlam türünün klasik Türkçe tıp metinlerinde sıklıkla kullanıldığı görülmüştür. Bu anlam, geniş zamanının, gerekliliğin, istek ve emir kipinin olumsuzunda yaygın olarak kullanılsa da sözcüksel birimlerle de işaretlenmektedir:

Bir dānıḳdan ziyāde isti 'māl olunmaz (KTTD, 92b/2)

Bir yıldan tecāvüz eyleyeni yimesünler (KTTD, 76b/15-16)

Sünbül ve zirişk ['anberbārīs] ve gāfiṣ [koyunotı] ve kāsnī [hindibā] gibi ol otlar kim ziyānkārdur anları fā'idelü otlara ḳatmayınca isti 'māl ètmeyeler (TA, 11a/17-11b/1)

Ve ba '̇̀ devālar ki ḥubūbdur meselā rāziyāne toḩumı gibi pek dögmemek gerek mi dede ziyādece eglensün içün (GM, 26a/3-5)

Veremi olan kişi ța 'ām yeyüp ḥareket ve cimā' eylememek ve ḥammāma girmemek gerek ve şiş uc verüp işledükden șoñra müshil içmemek gerek (MŞ, M136b/14-15)

\section{Emir}

Özellikle ikinci şahıslarının yükümlülük kipliği ile ilişkili olduğu söylenilen emrin, klasik Türkçe tıp metinlerinde kullanıldığı belirlenmiştir. Bu metinlerde emir anlam, emir kipi hariç, geniş zamanın ve istek kipinin olumsuzuyla da kullanılmıştır:

Göresiz şol ḥanzalı kim aġacında yaluñuz/Ola alman anı zinhār olur ol gāyet yavuz (M, 52b/13)

Yaramazdur öldürür itmeñüz isti 'māl anı/Böyle diyü pend idüpdür ehl-i ț̣b işit beni ( $M, 52 b / 3)$

Hem otuz altı direm toḩmını kāsnīnüñ girü/Yaru dögilmiş ola ḳaynadıban süzgil ‘amū (M, 48a/1)

Ve tiryāḳ-ı erba 'ayı galīẓ rīḥi olan isti 'māl eylesün (KTTD, 113b/7) 
Ve ḳızıl olanı demevī olanlar isti māl eylemesün (KTTD, 127b/16)

Diñlegil nice düzilür işbu ḩaşḩaşdan şarāb/Kabıla toḩmıla ḩaşhaşı dögeler iy şebāb (M, 48a/14)

\section{İzin verme/yükümleyen olanaklılık}

İzin verme de klasik Türkçe tıp metinlerinde sıklıkla kulanılan kiplik anlamlardandır. Olumlu cümlelerde ortaya çlkan izin verme anlamı, olumsuz cümlelerde yerini izin vermemeye bırakmıştır. İzin anlamı, istek ve emir kipi, edilgen fiillerde kullanılan geniş zaman yanında cayiz gibi kiplik sözler ve cayiz gör-, istimal olın- gibi kiplik fiillerle; izin vermeme anlamı ise, istek, emir kipinin olumsuzu, edilgen fiillerde kullanılan geniş zamanın olumsuzunda ve cayiz görme-, istimal olunma- gibi kiplik fiillerde ortaya çıkmaktadır. Bunlarla ilgili metinlerden alınan örnekler aşağıdaki gibidir:

Cemī cānavarlar soḳdugùna tiryāḳ-ı faruḳ vireler (KSE, 390/16)

siñirlüce otı șuyıyla içeler (MM, 123b/13)

șuyına yag ve bal ḳatalar (MM, 127a/5)

Mādām ki 'aḳl-ı șahịḥ ola ve havāssı yerinde ola isti ' māli (10) cāyizdir ve illā cāyiz degildir. Ve bundan bilinür. (KTTD, 128a/9-10)

Var-durur andan baġarsuklara çok ziyan/Yaramazdur öldürür itmenüz isti 'māl anı (M, 52a/13)

Göresiz şol ḥanzalı kim aġacında yaluñuz/Ola alman anı zinhār olur ol gāyet yavuz (M, 52b/13)

Omuz çıḳugin yẻrine ḳomasın beyān èder şöyle bilesin kim evvel gerekdür elüñile yapuşasın ve göñlüñile danışasın göresin żikr ètdügümüz nişānları teşhīṣ ẻdesin ḳanġısıdur aña göre işleyesin ve ol kişinüñ yaşını ve tabī'atını teşhīṣ ėdesin andan işleyesin evvel çekmek budur omuz çıkugùı yẻrine ḳomasın beyān ėder şöyle bilesin kim evvel gerekdür elüñile yapuşasın ve göñlüñile danışasın göresin zikr ètdügümüz nişānları teşhīṣ èdesin kanğısıdur aña göre işleyesin ve ol kişinüñ yaşını ve țabī'atını teşhīṣ èdesin andan işleyesin evvel çekmek budur kim ol kişiyi yaturasın ol hasta yanını yoḳaru koyasın ve bir țop hāzır ola böyüklügi şalgam deñlü ola ve ḳuşağı ol çıḳmış ḳolına bag̉layasın bir ucunı dirsekden yoḳaru ve bir ucunı ardına ve ol ḳuşaġı kendü bẻlüñe geçüresin ve bir ḳuşaḳ dahı bulasın ve ol ḳuşaġı da ol kişinüñ ḳoltuġı dibinden ve ol țopuñ üzerinden geçüresin (CM, 16a/13-15-16b/1-6)

\section{Uyarı}

Uyarılar da birisini bir işten vazgeçirmek veya bir işin yapılması veya yapılmaması konusunda eyleyiciyi etkilemek durumunda olduğu için yükümlülük kipliğine dâhil edilen anlamlardandır. Klasik Türkçe tıp metinlerinde de sağlık söz konusu olduğu için ilaçların kullanımları, hazırlanmaları noktasında hastalara ve onu uygulayacaklara uyarılar yapılmaktadır. Bu anlamların söz konusu metinlerde hazer, ziyan, ihtiraz, kan işet-, cenini iskat it- gibi sözlerle ve onların yardımcı fiillerle kullanılmış kiplik fiil şekilleriyle ve olumsuzlukla birlikte kullanılan gereklilik, emir ve istek kipiyle ortaya çıktı̆̆ı söylenebilir:

Yimesinde pes gerek-durur be-gāyet gey ḥazer/iki dirhem kim yidiyise öldürür budur haber (M, $5 \mathrm{ob} / 6)$

Hem dimağı daḩı arıdur velīkin iy cüvān/Var-durur andan baġarsuklara çok ziyān (M, 52a/13)

yaş yemişlerden ve bārid șulardan iḥtirāz ideler (MM, 163b, 19-20)

Bu cevārīşi isti 'māl èden kişi kendüyi incidmeye (TA, 94b-13)

bedene żarar ider (GM, 20a/8)

Tenbīh şarābıñ isti 'māline vācibdir fużūlıñ mürā'āti ve bir fașılda olan eyyāmıñ mürā āti ve sā'ātiñ mürā āti ve emziceniñ ve vilāyetleriñ (KTTD; 127b/12-13)

Ve istisḳāsı olan anıñ yemesinden ḥazer itsün (KTTD, 81a/20)

Ve eger bir kimse semizlik ve bedeni yumşaḳ olmasın isterse geymegini ictināb eylesün (KTTD, $225 \mathrm{~b} / 5-6)$ 
ḥayż ḳanın ve sāyir fażalātı cārī ider ve cenīni isḳāṭ ider ḥatta ḳan işedirmuṭlaḳan egerçi buhūr eylemek ile (KTTD, 252b/19-20)

\section{Tavsiye}

Tavsiyeler de bir kişinin nasıl davranacağı ve ne yapacağı konusunda etkileyen ifadelerdir. Bundan dolayı yükümlülük kipliği ile ilgilidir. Bu ifadelerde doğrudan güçlü bir yaptırım yoktur. İşin yapılıp yapılmaması tercihe bırakılmış gibidir, ancak yine de yapılmasından yana bir yönlendirmenin ağır bastığı/basacağı düşünülebilir. İncelenen metinlerde bu kiplik anlamın emir ve istek kipi yanında, fayide it-, eyü ol- gibi kiplik fiillerle ve eyü, faidelü, laylk gibi kiplik sözlerle ifade edildiği gözlenmiştir:

Fāyide ider dahı hem ag̈rısın başun keser (M, 5ob/12)

Eyüdür öksürüge gögüze sevdāyı sürer (M, 51a/7)

Eger bādām yaġınuñ içine rūfiz̄ūn yumurda șarusın çalḳasalar gaargara etseler gāyet eyüdür (MŞ, M64a/10-11)

șafrāvī kan buhārıdır 'alāmeti ıssı olmak ve kızıl olmak ve tezcek çıkmak ve gündüz harekete gelmekdür 'ilācı ḳan almak ve nüḳu '-1 müshil ve mâ' ü'l-rummāneyn ve nüḳù '-1 hulūv ve nüḳu' -1 hâamıż içmekdür ve et yemekden sakınmaḳdur sirkeyile mercimek aşı habbü’l-rummāneyn müzevveresi ya șumāḳ müzevveresi ve semüz ot müzevveresi kuru kişnicile yeyeler (MŞ, M134a/12-15-M/134b/1)

Ol, mașnū larıñ evlāsıdır ve terkībleriñ ahssenidir (KTTD, 42b/7)

bürūdıñ isti 'māliniñ eyüsi oldur ki altun melçe ile isti 'māl olına (KTTD, 42b73-4).

Ve maḥrūreyne lāyık olan budur ki anı aç ḳarına isti māl eyledikde gezineler (KTTD, 49a/18-19).

Görüldüğü gibi dil bilimsel kiplik çalışmalarında ifade edilen yükümlülük kipliğinin özellikleri ve kiplik anlamlarının klasik Türkçe tıp metinlerinden örneklenmiş ve belirlenmiştir.

\subsection{Yükümlülük kipliğinin kiplik alanları}

Doğrudan yükümlülük kipliğinin kiplik alanları ile ilgili bir çalışmaya rastlanmamıştır. Bundan dolayı bu bölümde onun kiplik alanları, genel hatlarıyla, ilgili olduğu gereklilik ve zorunluluk kiplik alanları ile somutlaştırılmaya çalışılmış ve klasik Türkçe tıp metinlerinin bu alanlardan hangisine dâhil olacağı veya olamayacağı tartışılmıştır. Gereklilik ve zorunluluk kiplik alanları ile ilgili olarak Papafragou'nun çalışmasından yararlanılmıştır. O gereklilik ve zorunluluk kiplik anlamlarının ayrıt edilmesi noktasında bu alanları belirlemiş̧ir. Bunun yanında yükümlülük kipliği ile ilgili diğer araştırmacılarda zikredilen alanlardan Kratzer, ahlakî (Kratzer, 1981), Nuyts-Byloo-Diepeveen bu terimi açıklamış (Nuyts-BylooDiepeveen, 2005); Palmer direktifler gibi (Palmer, 2001) uygun görülenler Papafragou'da geçen ilgili alanlara dâhil edilmiş, farklı görülenlere de ayrı bir başlık açılmıştır (Papafragou, 2000).

Papafragou'ya göre zorunluluk kiplik alanı, "düzenleyiciler, inanca dayalı alanlar ve sosyal alanlar; gereklilik ise ideal-merkezli alanlar, olağan merkezli alanlar ve kişisel inanç ve görüşler ile istekler”dir. Yukarıda da ifade edildiği gibi bunlar gereklilik ve zorunluluk anlamı bir kenara bırakılarak yükümlülük kipliğinin alanı olarak değerlendirilmiştir (Papafragou, 2000).

Bunlara göre yükümlülük kipliği alanları aşağıdaki gibi belirlenmiştir:

a) Düzenleyiciler (örn. yasa, yasak, kanun, kural, otorite),

Yasa

Yasak 
Kanun

Kural

Otorite

Sosyal kurallar

b) İnanca dayah alanlar (günah, dini kural),

Günah

Dinî kural

c) Sosyal alanlar (toplumsal yaptırm, ayıp, gelenek-görenek)

Toplumsal yaptırım

Ayıр

Gelenek Görenek

ç) İdeal-merkezli alanlar (ideal-centered domains)

d) Olağanmerkezli alanlar (normative domains)

e) Kişisel inanç ve görüşler ile istekler'

Kişisel inanç

Görüş

İstek

\section{f) Ahlakî kurallar}

\section{g) Direktifler}

Bu başlık ve alt başlıklara göre klasik Türkçe tıp metinleri değerlendirilirse, onun yasa, kanun, kural olmadığı; kişisel inanç, görüş, istek, ideal merkezlilik, olağanlık yansıtmadığı görülebilir. Bu noktada onun mevcut araştırmalarda dile getirilen kiplik alanlara dâhil olamayacağı düşünülmektedir. Bu noktada klasik Türkçe tıp metinleri ve hatta tıp metinlerinin farklı bir kiplik alana sahip olduğu ve bunun da kural koymadan, kanundan ve kişisel inanç ve görüşten farklı olarak kişiye zorunluluk ve gereklilik bildirdiği veya izin veren ifadeleri içerdiği söylenebilir. Tıp metinlerindeki hekimin tavrı, Palmer'de bir iş yapma konusunda birinin seçilmesi olarak betimlenen direktiflere uyumlu olsa da kişide ilgili hastalık bulunmazsa, hekimin, ilacı kullanma konusunda da hastayı görevlendireyim gibi bir durum içerisinde olacağı düşünülmemektedir. Bunlardan dolayı bu metinlerin yükümlülük kiplik alanı içerisindeki yerinin ayrıca tartışılması gerektiği düşünülmektedir.

Tarafımızca tıp metinleri, sağlığa doğrudan etki eden, içerdikleri gereklilik ve yükümlülüklerle insanı doğrudan ilgilendiren yaptırımlara sahiptir. Bu yüzden onların, tıp ve sağlık gibi başlı başına bir kiplik alanı ile değerlendirilmesi gerekir. Yine bu alana, eczacılık, tedavi usulleri, beslenme yolları, ilaç hazırlama teknikleri, koruyucu hekimlik gibi alt dallar da ilave edilebilir.

\section{Sonuç ve değerlendirme}


Yükümlülük kipliği, temel olarak zorunluluk ve izin ile ilişkilendirilmektedir. Bunun yanında o, çeşitli kuramlarca farklı özelliklerle de ifade edilmektedir. İnceleme bölümünde de görüldüğü gibi klasik Türkçe tıp metinleri, onunla ilgili tüm tartışmaları içerecek örneklere ve kullanımlara sahip bir metin türüdür.

Klasik Türkçe tıp metinlerinde konuşur yani hekim, tedavi olmak isteyene göre bilgisine güvenilen ve sağlık konusunda söz sahibi olan otorite konumundadır. Bu da yükümlülük kipliği ile doğrudan ilgili bir özelliktir.

Yükümlülük kipliği kiplik anlamları içerisinde ele alınan anlamlar, söz konusu metinlerde yer almaktadır.

Yükümlülük kipliği kiplik alanları ile ilgili dorğudan bir çalışma bulunmamaktadır. Onun ilgili olduğu gereklilik ve zorunluluk ile ilgili kiplik alanlara klasik Türkçe tıp metinlerinin, dolayısıyla tıp metinlerinin dâhil edilemediği görülmüştür. Bundan dolayı bazı metin türleriyle beraber yükümlülük kiplik alanlarının kapsamlı bir şekilde ele alınması gerekliliği tespit edilmiştir.

Klasik Türkçe tıp metinlerinin gerek yükümlülük kipliği özellikleri gerekse kiplik anlamları ile ilgili tüm özellikleri karşıladığı ve yükümlülük kipliği ile doğrudan ilgilendirilebilecek bir metin türü olduğu ifade edilebilir. Ancak dil bilimsel kiplik çalışmalarında onun istenilen düzeyde ele alınmadığı görülmüştür.

Klasik Türkçe tıp metinlerindeki kiplik anlamların dağılımları yani sıklığı ilerleyen dönemlerde yapılacak istatiksel çalışmalarla ortaya konulabilir. Ancak onlarda tüm hastaları ilgilendiren ve doğrudan bir kişiyi görevlendirmeyen gereklilik anlamının sık kullanıldığı gözlenmiştir. Bunun yanında yasaklama, emir, izin, tavsiye ve uyarı anlamlarının da yaygın kullanıma sahip olduğu da sınırlı örneklerde bile görülmüsstür.

\section{Tartışma}

Klasik Türkçe tıp metinleri, hangi yükümlülük kiplik alanında yer almalı ve bu alan nasıl adlandırılmalıdır?

Klasik Türkçe tıp metinlerinde yükümlülük kipliğinin kullanım sıllığı nedir?

Metin türleri ile kiplik türleri arasında istatistiksel çalışmalar yapılmalı mıdır?

Metin türleri ile kiplik türleri arasında bir ilişki var mıdır? Eğer böyle bir ilişki varsa bunlar nasıl tespit edilebilir?

\section{7. Öneriler}

Klasik Türkçe tıp metinlerinin yükümlülük kipliği alanlarında ayrıca değerlendirilmesi gerektiği düşünülmektedir. Çünkü tıp konusundaki her uygulamanın kanunlar ve kurallar gibi herkesi kapsamadığı düşünülmektedir. Ancak bununla birlikte onların aynı grup hastalıklar için ortak bilgiler içerse de kişiden kişiye değişebilecek yaptırımlara sahip olabilecek nitelikte olduğu rahatlıkla ifade edilebilir. Bundan dolayı tıp ve sağlıkla ilgili bilgilerin ve onlardan kaynaklı öneri ve yaptırımların ayrı bir kiplik alanla değerlendirilmesi gerekmektedir. Bu yükümlülük kipliği alanı için tıp ve sağlık başlığı önerilmektedir. Elbette bu, üzerinde çalışılması ve tartışılması gereken bir kiplik alan önerisidir. 


\section{Kaynakça}

Akbayır, S. (2004). Metin Bilgisi, Okuma Anlama, Yorumlama, Çözümleme, Samsun: Deniz Kültür Yayınları.

Aksan, M.-Aksan, Y. (1991). "Metin Kavramı ve Tanımları", Dilbilim Araştırmaları, Ankara, s. 90-104.

Arslan, M. (2014). Kitâb-ı Tercüme-i Težkire-i Dâvûd Fì İlmi't-Tıbb (Metin-Dizinler-Sözlük), Çukurova Üniversitesi Sosyal Bilimler Enstitüsü Yayımlanmamış Doktora Tezi, Adana.

Aslan Demir, S. (2008). Türkçede İsteme Kipliği, Semantik - Pragmatik Bir İnceleme. Ankara: Grafiker.

Bybee, J. L.-Pagliuca, W.-Perkins, R. D. (1994). The Evolution of Grammar: Tense, Aspect and Modality in the Languages of the World, Chicago: University of Chicago Press.

Canpolat, M.-Önler, Z. (2007). İshak bin Murad Edviye-i Müfrede (Metin-Sözlük), Ankara: TDK.

Corcu Gül, D. (2005), “Zorunluluk Kipliği Belirtisi -mAlI’nın Anlamsal İçyapısı”, Dilbilim Araştırmaları Dergisi, s. 33-44.

Çetin, O. A. (2011). Türkiye Türkçesinde Gereklilik Kipliği, Bozok Üniversitesi Sosyal Bilimler Enstitüsü yayımlanmamış Yüksek Lisans Tezi, Yozgat.

Çetres, İ. H. (2014). Modal Mantıkta Sıkı İçerme Kavramı, İstanbul Üniversitesi Sosyal Bilimler Enstitüsü Mantık Anabilim Dalı, Yayımlanmamış Yüksek Lisans Tezi, İstanbul.

Demirtaş, A. (2008). "Dede Korkut Hikâyelerinde "Gerek" Kelimesi İle Kurulu Cümleler”, Turkish Studies 3(1) Winter, s. 14-21.

Dinar, T. (2013). Müderris Hasan Efendi’nin Gayetü'l-Münteha Fi-Tedbiri'l-Merza'sı (Hastahklarn Tedavisinde En Son Nokta) (İnceleme-Metin-Dizinler), Pamukkale Üniversitesi Sosyal Bilimler Enstitüsü Yayımlanmamış Doktora Tezi, Denizli.

Doğan, Ş. (2009). Terceme-i Akrâbâdîn Sabuncuoğlu Şerefeddin (Giriş-İnceleme-Metin-Dizinler), Sakarya Üniversitesi Sosyal Bilimler Enstitüsü Yayımlanmamış Doktora Tezi, Sakarya.

Erk Emeksiz, Z. (2008). “Türkçede Kiplik Anlamının Belirsizliği Ve Anlamsal Roller”, Dil Dergisi, Sayı: 141, s. 55-66.

Güven, M. (2015), “Kıbrıs Ağzında Gereklilik Üzerine”, Dilbilim Araştırmaları Dergisi, 2, s. 1-24.

İhsanoğlu, E.-Şeşen, R., v.d. (2008). Osmanl Tıbbi Bilimler Literatürü Tarihi. (C. 1), İstanbul: IRCİCA.

Jahangirov, F. (2011), On The Problem Of Modality in Germanic and Turkic Languages, Intern inational Journal of Arts/Sciences, 4 (18): 297-309.

Kartal, D. (2016). Ahmed Bin Bâlî - Mecmaü’l - Mücerrebât (Giriş - İnceleme (Şekil Bilgisi) - Metin Dizinler [116-166. Varaklar Arası]-Sözlük), Abant İzzet Baysal Üniversitesi Sosyal Bilimler Enstitüsü, Yayımlanmamış Yüksek Lisans Tezi, Bolu.

Kaya, E. (2008). Muhyiddin Mehînin Müfid (Nazmü̈t-Teshîl) Adlı Eseri (İnceleme-Metin-Dizin) ve Bu Eserin XV. Yüzyıl Türk Tip Dilinin Oluşmasındaki Yeri, Selçuk Üniversitesi Sosyal Bilimler Enstitüsü Yayımlanmamış Doktora Tezi, Konya.

Kerimoğlu, C. (2011). Kiplik İncelemeleri ve Türkçe, İzmir: Dinazor.

Kitāb Eczā-i Lokmān Hekīm, Vatikan Türkçe Eserler 430.

Köz, İ. (2003). 'Modal Mantıkta Strict Implication-MateriaI Implicatio' (Sıkı Gerektirme-Modal Gerektirme)” Ankara Üniversitesi İlahiyat Fakültesi Dergisi, Cilt XLIV, Sayl 1, s. 161-171.

Kratzer, A. (1981) "The Notional Category of Modality" Words, Worlds and Contexts- New Approaches in Word Semantis, (editor: Hans-Jurgen Eikmayer and Hannes Rieser) Berlin: Walter de Gruyter, s. 38-75.

Lyons, J. (1977). Semantics. England: Cambridge University Press. 
Malak, B. (2013). Mantıkta Modalite Kavramı ve Tarihçesi, İstanbul Üniversitesi Sosyal Bilimler Enstitüsü Felsefe Bölümü, Yayımlanmamış Yüksek Lisans Tezi, İstanbul.

Narrog, H. (2012). Modality, Subjectivity and Semantic Change, Oxford University, Newyork: Oxford University Press.

Nuyts, J.-Byloo, P.-Diepeveen, J. (2005), “On deontic modality, directivity, and mood A case study of Dutch mogen and moeten”, Center for Grammar, Cognition and Typology University of Antwerp, Antwerp Papers In Linguıstics, Belgium, s.1-56.

Öner N. (2009), Klasik Mantık. Ankara: Vadi.

Önler, Z. (1981). Celalüddin Hızır (Hacı Paşa) Müntehab-ı Şifa-İnceleme-Metin-Dizinler, Fırat Üniversitesi Edebiyat Fakültesi, Yayımlanmamış Doktora Tezi, Elazı̆̆.

Önler, Z. (1990). Celalüddin Hızır (Hacı Paşa) Müntehab-ı Şifa I, Giriş-Metin, Ankara: TDK.

Palmer, F. R. (2001). Mood and Modality. Cambridge: Cambridge University Press.

Papafragou, A. (2000). Modality: Issues in the Semantics-Pragmatics Interface. Amsterdam: Elsevier

Rentzsch, J. (2011a). "Modality in the Dede Qorqud Oguznameleri”. Acta Orientalia Hungarica, 64 (1), s. $49-70$

Rentzsch, J. (2013). Türk Dillerinde Kipsellik ve Kipselliğin Anlambilimsel Haritası. Bilig 67, s.129-168.

Telli, B. (2017). Kenzü’s-Sihhatü'l-Ebdâniyye Eser-i Mürşid-i Osmaniyye (İnceleme-Metin-Gramatikal Dizin-Tıpkıbasım), Adıyaman Üniversitesi Sosyal Bilimler Enstitüsü Yayımlanmamış Doktora tezi, Adıyaman.

Torun, Yeter, (2013), Türkçede Gelecek Zaman ve Kiplik Özellikleri. Adana: Karahan Kitabevi.

Türkçe Sözlük (2011, 11.bs.). Ankara: TDK.

Uçar, İ. (2009). Hazâ Kitâb-ı Hulâsa-i Tıbb Cerrâh Mes'ûd (Giriş-İnceleme-Metin-Dizinler), Sakarya Üniversitesi Sosyal Bilimler Enstitüsü Yayımlanmamış Doktora Tezi, Sakarya.

Ural, Ş. (1995). Temel Mantık, İstanbul: Çantay.

Uzdu Yıldız, F. (2011). Göstergebilim Kiplikleri Açısından Anlatı Kişilerinin İncelenmesi, Ege Üniversitesi Sosyal Bilimler Enstitüsü Yayımlanmamış Doktora Tezi, İzmir.

Van der Auwera, J.-Aguilar, A. Z. (2016). "The History of Modality and Mood”, (Editor Nuyts, JanAuwera, Johan van der (2016). The Oxford Handbook of Modality and Mood). Oxford University Press, s. 10-28.

Van der Auwera, J.-Plungian, V. A. (1998). “Modality's semantic map”. Linguistic Typology, 2: s. 79124.

Yarar, Ö. (2006). Anlatı Metinlerinde Metin Dünyasını Belirginleştiren Dilsel Düzenlemeler, Ankara Üniversitesi Sosyal Bilimler Enstitüsü, Yayımlanmamış Yüksek Lisans Tezi, Ankara.

Yavuz, Y. (2008). Hekim Hayreddin’in Kitab-ı Ākrābādīñi, Selçuk Üniversitesi Sosyal Bilimler Enstitüsü Yayımlanmamış Yüksek Lisans Tezi, Konya.

\section{Elektronik kaynakça}

https://dictionary.cambridge.org/dictionary/english/commission

https://glossary.sil.org/term/text 